\title{
IMPROVING HUMAN DEVELOPMENT: A LONG-RUN VIEW
}

\author{
Leandro Prados de la Escosura \\ Universidad Carlos III, Madrid
}

\begin{abstract}
The pessimistic flavour of the Human Development Reports appears to be in contradiction with their own numbers as developing countries fare comparatively better in human development than in per capita GDP terms. This paper attempts to bridge this gap by providing a new, 'improved' human development index (IHDI), informed by welfare economics. The IHDI is presented here alongside the United Nations Development Programme's (UNDP) HDI for the world and its main regions since the late 19th century. Social dimensions in the IHDI are derived, following Kakwani (Journal of Development Economics 41 (1993), pp. 307-336), with a convex achievement function, whereas a geometric average is employed to combine its dimensions (longevity, knowledge and income). Thus, the IHDI does not conceal the gap between rich and poor countries and casts a much less optimistic view than the conventional UNDP index, while it fits with the UNDP concern for international differences. The paper's findings highlight main weaknesses in human development dimensions of present-day developing countries.
\end{abstract}

Keywords. Education; Human development; Life expectancy; Per capita GDPs

Readers of the Human Development Report (HDR), published periodically by the United Nations Development Programme (UNDP), tend to have mixed feelings. The pessimistic rhetoric of the HDR seems to be contradicted by its own numbers. In fact, when weighed up in human development terms, developing countries tend to fare better relative to advanced countries than in per capita income terms.

It is the purpose of this essay to bridge the gap between the empirical evidence on human development and the HDR rhetoric by providing a new, 'improved' index (IHDI, hereafter), informed by welfare economics. ${ }^{1}$ The IHDI is presented here along the UNDP's HDI (UNHDI, henceforth) for the world and its main regions over the period 1870-2005.

What defines the new human development index? In the first place, its social, non-income dimensions are derived using a convex achievement function as an alternative to the linear transformation employed in the UNHDI. Thus, in the new index, as a social indicator reaches higher levels, its increases represent higher achievements than if the same increase would take place at a lower level, whereas in the UNDP linear transformation the same change results regardless of the starting level. Second, in an attempt to reduce substitutability among the index components, 
its three dimensions (longevity, access to knowledge and average incomes) are combined into the new IHDI using a geometric average, rather than the arithmetic average used in the UNHDI. The final outcome is a new human development index which, by not concealing the gap between rich and poor countries, casts a much less optimistic view than the one provided by conventional UNDP index while satisfying the HDR concern for international differences.

The paper is organized in four sections. Section 1 assesses the UNHDI and exposes its main shortcomings. In an attempt to provide a response to these objections Section 2 presents the new IHDI. Then, world trends in human development since the late 19th century, derived from both the IHDI and the UNHDI, are compared in Section 3. Some concluding remarks complete the paper.

\section{Assessing the Human Development Index}

Challenging GDP (or GNP) per head as a measure of welfare, in spite of its advantage as a synthetic index and the observed association between economic growth and welfare (Lewis, 1955; Beckerman, 1993), has been recurrent since the spread of national accounts more than half a century ago (United Nations, 1954; Dasgupta, 1993; Engerman, 1997; Fleurbaey, 2009). Different socio-economic indicators have been explored as an alternative to GDP per head among which the basic needs approach and the physical index of quality of life are widely known. ${ }^{2}$ The UNHDI, a synthetic product of the UNDP, published annually since 1990, has been the latest addition to these social welfare measures. Although, on this occasion, the index has reached beyond academic borders, as a measure of well-being the UNHDI has not escaped strong criticism. ${ }^{3}$

Human development was originally defined as 'a process of enlarging people's choices' that enables them 'to lead a long and healthy life, to acquire knowledge and to have access to resources needed for a decent standard of living' (UNDP, 1990, p. 10). In other words, human development emphasizes positive freedom (Desai, 1991, p. 356). As a synthetic measure of human development, the UNHDI tries to capture a country's achievements in longevity, knowledge and standard of living through various indices: the relative achievement in life expectancy at birth, in education and in 'all dimensions of human development not reflected in a long and healthy life and in knowledge' for which the adjusted per capita GDP (its logarithm) is a surrogate (UNDP, 2001, p. 240). These achievements provide individuals the freedom to choose (Kakwani, 1993; Fleurbaey, 2009) and, thus, the opportunity 'to lead lives they have reasons to value' (Sen, 1997).

Indices for each dimension $(I)$ are computed according to the following formula,

$$
I=(x-M o) /(M-M o)
$$

where $x$ is the observed value of a given dimension of welfare, and $M o$ and $M$ represent the maximum and minimum values, or goalposts. Goalposts representing levels not reached yet and below the present's lowest level, respectively, were chosen for each indicator in order to make possible comparisons over time. ${ }^{4}$ Each 
dimension ranges, thus, between 0 and 1 . The UNHDI is obtained as the unweighted arithmetic average of the three dimension indices.

Reactions to non-conventional indicators of well-being have always been critical. One of the most popular synthetic indices, Morris's (1979) physical quality of life index (PIQL; an unweighted average of normalized indices of infant mortality, life expectancy and literacy) was seriously questioned on the basis of the high collinearity between its first two components (Hopkins, 1991) and has only made an uncritical comeback in the historical literature (Federico and Toniolo, 1991; Domínguez and Guijarro, 2000). ${ }^{5}$

The UNHDI, presumably an improvement on Morris's PIQL, has been seriously questioned (Dasgupta, 1993, p. 77). ${ }^{6}$ Srinivassan (1994, p. 240), for example, described the new index as 'conceptually weak and empirically unsound, involving serious problems of non-comparability over time and space', whereas Dowrick et al. (2003) stressed its lack of welfare economics foundations. Moreover, the distribution of each dimension of the index is not taken into account. ${ }^{7}$ Furthermore, the weakness of the data underlying UNHDI (incomplete coverage, measurement errors and biases) has been highlighted as a major shortcoming of the new index (Srinivassan, 1994). ${ }^{8}$ GDP per head estimates for developing countries are highly questionable (Heston, 1994). Moreover, literacy and enrolment data are frequently non-homogeneous making comparisons difficult. ${ }^{9}$ Lastly life expectancy data tend to be interpolated and often obtained through life tables' projection rather than through direct estimation. ${ }^{10}$

Major critical issues of the human development index are: How to transform the original values of social dimensions into indices? Should a linear or a non-linear transformation be used? Do human development dimensions (longevity, education and income) provide different insights of welfare, or are they simply redundant? If they capture different welfare dimensions, should equal weights be allocated to each dimension and kept unaltered over time? How to combine the main dimensions of well-being? Is an arithmetic average the appropriate procedure? ${ }^{11}$

The choice of UNHDI's components has provoked an endless debate. For example, the inclusion of average incomes in the index of human development raises two distinctive issues. On the one hand, if those dimensions of human development 'not reflected in a long and healthy life and in knowledge' need to be considered, why is income per head chosen as a proxy? Is it just because of its availability? On the other hand, why imposing a diminishing marginal utility on income? Against the view that a decent standard of living does not require unlimited income it has been opposed that 'additional income above the threshold can allow more human development' (Gormely, 1995, p. 264) and that it is only above a given threshold that per capita income becomes relevant for human development (Sagar and Najam, 1998, pp. 253-254). Furthermore, it has been argued that a non-modified GDP per head 'may be appropriate for long run welfare comparisons if the focus is broader than just the escape from poverty' (Crafts, 1997, p. 304). In the case of education, it is commonly accepted that, for developing countries, literacy is an essential element of human development, but it becomes meaningless for developed countries, when literacy rates are close to $100 \%$ (see, for example, 
Lindert, 2004). Fortunately, a wider range of variation is permitted by the aggregate enrolment rate for primary, secondary and tertiary education, also a component of the UNHDI educational dimension.

The aggregation of each dimension into a synthetic index has provoked some adverse reactions. For example, Kakwani (1993) and Aturupane et al. (1994) suggested the use of socio-economic indicators separately, whereas Dasgupta and Weale (1992) proposed an ordinal rather than cardinal measure of well-being, which was also made more inclusive by incorporating civil and political liberties.

Does each UNHDI component measure a different aspect of well-being, or is it highly correlated to the rest of them? ${ }^{12}$ Previous attempts to derive alternative welfare indices to conventional GDP per head suffered from either a high correlation with GDP, or were obtained from highly correlated components that rendered them redundant. There has been some outright rejection of the UNHDI. For example, McGillivray (1991, p. 1467), after stressing the positive correlation among the index's individual components, concluded that the UNHDI was 'yet another redundant composite intercountry development indicator'. A way of establishing whether the indicators included under the umbrella of human development did capture different aspects of well-being has been to use principal components analysis (PCA). ${ }^{13}$ PCA allows one to establish whether the human development index attributes are redundant or add information on different facets of well-being. ${ }^{14}$ This way it was found that the three dimensions contained in the UNHDI belonged to the same component and, therefore, the simultaneous use of the three attributes is justified despite its high cross-correlation (UNDP, 1993, pp. 109-110). ${ }^{15}$

The weighting system is a major objection to the UNHDI (Hopkins, 1991; Booysen, 2002). Should each dimension (longevity, education and income) receive the same weights in the index over space and time? ${ }^{16}$ This choice finds support in the notion that each of them is equally essential in determining its level, a feature considered to be a main attribute of the human development concept (Sagar and Najam, 1998, p. 251). ${ }^{17}$ However, it has been argued, UNHDI weights are based on judgment rather than on welfare economics (Dowrick et al., 2003 , p. 504). A substantive objection to the use of fixed weights is that the relative values of the index components are not necessarily the same across countries (or individuals) and over time (Srinivassan, 1994, p. 240). Historical evidence on the relationship between life expectancy and per capita income lends support to this assertion (Preston, 1975). ${ }^{18}$ Modern economic growth predated improvements in life expectancy but the latter spread more rapidly (Easterlin, 1999). A technical solution is offered by PCA. Its results provide optimal weights for each HDI component over time by weighting attributes by their variance ${ }^{19}$ and, counterintuitively, suggest stable one-third weights for each dimension of the index. ${ }^{20}$

An additional difficulty is that attainments in each component are traded off against each other but these tradeoffs are not explicit. A close examination of the implicit tradeoffs offers some surprising results. For example, the implicit monetary valuation of an extra year of life expectancy rises dramatically with income as, by construction, the UNHDI implicitly values life relatively less in poor than in rich countries. $^{21}$ 
Is the unweighted arithmetic average of all dimensions (longevity, education and income) an acceptable way to derive a synthetic human development index? It has been noted that additivity over these attributes implies perfect substitution, which contradicts the notion that each dimension is equally crucial in determining the level of human development. Hence, it has been suggested that the substitutability among the index components should be restricted through their geometric average (Desai, 1991, p. 356; Sagar and Najam, 1998, pp. 251-252) since with a multiplicative procedure the human development index will only experience a significant improvement if each of its dimensions does it.

How should the original values of social dimensions be transformed into wellbeing indices? An objection to the linear transformation of the original values in the UNDP approach to human development was made by Srinivassan (1994, p. 240) who pointed out that "the "intrinsic" value of a single "functioning", namely, the ability to live a healthy life, is not captured by its linear deprivation measure in UNHDI, since a unit decrease in the deprivation in life expectancy at an initial life expectancy of, say, 40 years is not commensurate with the same unit decrease at 60 years'.

The nonlinearity of the relationship between the value of each social indicator and its achievement, so that the observed differences in the levels of social indicators do not reflect their true achievement, has been thoroughly explored by Kakwani (1993), who stressed that social indicators such as life expectancy, infant mortality or literacy have, in opposition to GDP per head, asymptotic limits, reflecting physical and biological maxima.

Using an axiomatic approach Kakwani (1993) constructed a normalized index from an achievement function in which an increase in the standard of living of a country at a higher level implies a greater achievement than would have been the case if it occurred at a lower level: ${ }^{22}$

$$
\begin{aligned}
\mathrm{f}\left(x, M_{0}, M\right) & =\left(\left(M-M_{0}\right)^{1-\varepsilon}-(M-x)^{1-\varepsilon}\right) /\left(M-M_{0}\right)^{1-\varepsilon} \text { for } 0<\varepsilon<1 \\
& =\mathrm{f}\left(x, M_{0}, M\right) \\
& =\left(\log \left(M-M_{0}\right)-\log (M-x)\right) / \log \left(M-M_{0}\right) \text { for } \varepsilon=1
\end{aligned}
$$

where $x$ is an indicator of a country's standard of living, $M$ and $M_{0}$ are the maximum and minimum values, respectively, and $\log$ stands for the natural logarithm. The achievement function proposed by Kakwani (1993, p. 314) is a convex function of $x$, and it is equal to 0 if $x=M_{0}$, and equal to 1 if $x=M$, ranging, then, between 0 and 1.

In fact, the UNHDI represents a particular case, for $\varepsilon=0$, which yields expression (1) for each dimension of the index. Such particular case does not satisfy, however, one of the axioms of the achievement index defined by Kakwani, namely, that the index should give greater weight to the improvement of a country which has higher level for each social indicator. This axiom follows 'from the belief that as the standard of living reaches progressively higher limits, incremental improvement should require much greater resources than similar incremental improvements from a lower base' (Kakwani, 1993, p. 312). 


\section{ESCOSURA}

Nonetheless, Kakwani's rationale can be challenged, for example, on the basis that an 'improvement in education attainment may not be more difficult as the level of education becomes higher and higher' (Tsui, 1996, p. 302). In fact, Noorbakhsh (1998) modified the human development index by extending the principle of diminishing returns to education (but not to longevity). The rationale is that 'under similar conditions the early "units" of educational attainments to a country should be of much higher value than the last ones' (Noorbakhsh, 1998, p. 519). Such assertion implies that the ethical and measurement aspects seem to be at odds in the human development index. However, as Dasgupta (1990, p. 23) rightly pointed out,

Equal increments are possibly of less and less ethical worth as life expectancy rises to 65 or 70 years and more. But we are meaning performance here. So it would seem that it becomes more and more commendable if, with increasing life expectancy, the index were to rise at the margin. The idea here is that it becomes more and more difficult to increase life expectancy as life expectancy rises. ${ }^{23}$

Therefore, the acceptance of Noorbakhsh's ethical argument for a 'modified' index would distort the measurement of performance, which is my main purpose here, by reducing the index variance of across countries and imposing, hence, artificial convergence across countries. ${ }^{24}$ Such a constraint on the index dispersion would only make sense if the single goal of the UNHDI were just measuring basic human development and not, as in our case, assessing the evolution of well-being over time.

\section{Introducing the 'Improved' Index of Human Development}

As a way to answering some of these queries I have constructed the IHDI in which its non-income dimensions are derived with a convex achievement function (i.e. using expression (3)). Thus, in the alternative human development index, IHDI, as a social indicator reaches higher levels, its increases represent higher achievements than had the same increase taken place at a lower level, whereas in the UNHDI they reflect the same change regardless its starting level.

Some minor changes have been introduced in the conventional goalposts so the maximum and minimum represent levels above the highest and below the lowest, respectively. ${ }^{25}$ For life expectancy at birth, although the conventional maximum, $M$, of 85 years has been kept, a minimum, $M_{0}$, of 24 years has been chosen, whereas 25 years has been accepted as the lowest historical level. ${ }^{26}$ For the education indicators (literacy and enrolment), although UNDP values of $M=100$ and $M_{0}=0$ have been kept, the highest and lowest historical values have been set at $99 \%$ and $1 \%$, respectively. $^{27}$

As regards per capita income, it is worth noting that, in international comparisons, dissatisfaction with nominal income (i.e. national GDP per head converted into a common currency using the trading exchange rate) has led to an almost generalized use of real income (the conversion per capita GDP into a common currency using a purchasing power parity (PPP) exchange rate) ${ }^{28}$ Unfortunately, the construction 
of PPP converters involves high costs in terms of time and resources. Only PPPs for a restricted country sample have been constructed for earlier periods, and most of them for output components. ${ }^{29}$

An indirect method to derive historical estimates of real per capita income levels for a large sample of countries is the backward projection of PPP-adjusted GDP per capita for a given benchmark with volume indices derived from national accounts data. ${ }^{30}$ It is worth noting that fixed-base real (PPP-adjusted) product data represent a most convenient alternative to carrying out painstaking direct comparisons across space and time and have the presentation advantage that their growth rates are identical to those calculated from national accounts. ${ }^{31}$ Alas, a distant PPP benchmark introduces distortions in inter-temporal comparisons because its validity depends on how stable the basket of goods and services used to construct the original PPP converters remains over time. As growth occurs over time the composition of output, consumption and relative prices all vary, and the economic meaning of comparing real product per head based upon remote PPPs becomes entirely questionable. Hence, using a single PPP benchmark for long-run comparisons implies a hardly realistic assumption: that no changes in relative prices (and, hence, no technological change) takes place over time.

Unfortunately, in the current state of research there is no alternative to the use of this approach, especially when a world country sample over one and a half centuries is considered.

Then, the UNHDI assumption that the marginal utility of per capita income declines as it reaches higher levels has been accepted. The reason to keep such an astringent assumption is that, following the UNDP proposal, this transformed measure is taken as a proxy for any well-being dimension outside health and education, and not for income per head. Therefore, the log of GDP per head is employed in expression (1) with a maximum of 40,000 Geary-Khamis 1990 dollars and a minimum of 100 dollars. Similar to the cases of social indicators, I have assumed a lower bound for per capita GDP, 300 Geary-Khamis 1990 dollars, which represents a basic level of physiological subsistence (Sagar and Najam, 1998, p. 254; Milanovic et al., 2007), which is below the World Bank's extreme poverty measure of one dollar a day/person and Maddison's (2006) 400 dollars per head. ${ }^{32}$

Finally, the three main dimensions of human development (longevity, knowledge and income) have been combined using a geometric average to derive the new IHDI. A geometric average of the human development attributes has the advantage of reducing their substitutability, precluding the chance that one attribute's improvement offsets another's worsening, as is the case with its arithmetic average employed in the UNHDI. Under the geometric average alternative, instead, only if all dimensions improve will an improvement in the human development index take place. Thus, if we denote by $L$ and $E$ the non-linearly transformed values of life expectancy and education, and by $Y_{\text {un }}$ the adjusted per capita income, the IHDI can be expressed as

$$
\mathrm{IHDI}=L^{1 / 3} E^{1 / 3} Y_{\text {un }}^{1 / 3}
$$


Table 1. Human Development in the World, 1870-2005: Alternative Estimates.

\begin{tabular}{|c|c|c|c|c|c|}
\hline \multirow[b]{2}{*}{ Panel A } & \multicolumn{2}{|c|}{ Levels } & \multirow[b]{2}{*}{ Panel B } & \multicolumn{2}{|c|}{ Annual growth rates } \\
\hline & IHDI & UNHDI & & IHDI & UNHDI \\
\hline 1870 & 0.064 & 0.196 & $1870-1880$ & 1.2 & 0.7 \\
\hline 1880 & 0.072 & 0.211 & $1880-1890$ & 1.6 & 0.9 \\
\hline 1890 & 0.085 & 0.231 & 1890-1900 & 1.5 & 0.9 \\
\hline 1900 & 0.098 & 0.253 & 1900-1913 & 1.2 & 0.7 \\
\hline 1913 & 0.115 & 0.278 & 1913-1929 & 2.1 & 1.1 \\
\hline 1929 & 0.159 & 0.333 & 1929-1938 & 1.8 & 1.3 \\
\hline 1938 & 0.187 & 0.375 & $1938-1950$ & 1.8 & 1.2 \\
\hline 1950 & 0.232 & 0.433 & $1950-1960$ & 2.0 & 1.6 \\
\hline 1960 & 0.283 & 0.507 & $1960-1970$ & 1.3 & 1.1 \\
\hline 1970 & 0.323 & 0.565 & 1970-1980 & 0.8 & 0.6 \\
\hline 1980 & 0.349 & 0.601 & 1980-1990 & 0.9 & 0.6 \\
\hline 1990 & 0.380 & 0.639 & 1990-2000 & 1.2 & 0.7 \\
\hline 2000 & 0.427 & 0.684 & $2000-2005$ & 1.3 & 0.8 \\
\hline \multirow[t]{7}{*}{2005} & 0.455 & 0.711 & & & \\
\hline & & & 1870-1913 & 1.4 & 0.8 \\
\hline & & & 1913-1950 & 1.9 & 1.2 \\
\hline & & & 1950-1970 & 1.7 & 1.3 \\
\hline & & & 1970-1990 & 0.8 & 0.6 \\
\hline & & & 1990-2005 & 1.2 & 0.7 \\
\hline & & & 1870-2005 & 1.5 & 1.0 \\
\hline
\end{tabular}

\section{Trends in Human Development}

Trends in aggregate human development have been computed for four different country samples for which time and spatial coverage are inversely related. Thus although only 88 countries are considered for the entire time span, 1870-2005, the number rises to 99, 134 and 156 countries for those samples starting in 1913, 1950 and 1990, respectively. Fortunately these samples represent more than $90 \%$ of the world population (and practically all since 1950). Interestingly, the results for regional aggregates in each of these samples are highly coincidental so the different indices can be spliced into a single one for each main world region. ${ }^{33}$

A substantial improvement in world human development is observed since 1870 and especially over 1913-1960, multiplying by seven its initial level. When the results for the IHDI and the UNHDI are compared, the same trend is confirmed, but for a significant difference in initial levels and an absolute gap widening between them as the IHDI lagged behind (Table 1 and Figure 1). In terms of the conventional HDR categories - 'low' $(<0.5)$, 'medium' (0.5) and 'high' (0.8) levels the average human development in the world, according to the IHDI, would still remain today in the 'low' category, whereas, for the UNHDI, the world belonged to the 'medium' level since 1960 and it is getting closer to the 'high' level. Thus, over 
IMPROVING HUMAN DEVELOPMENT

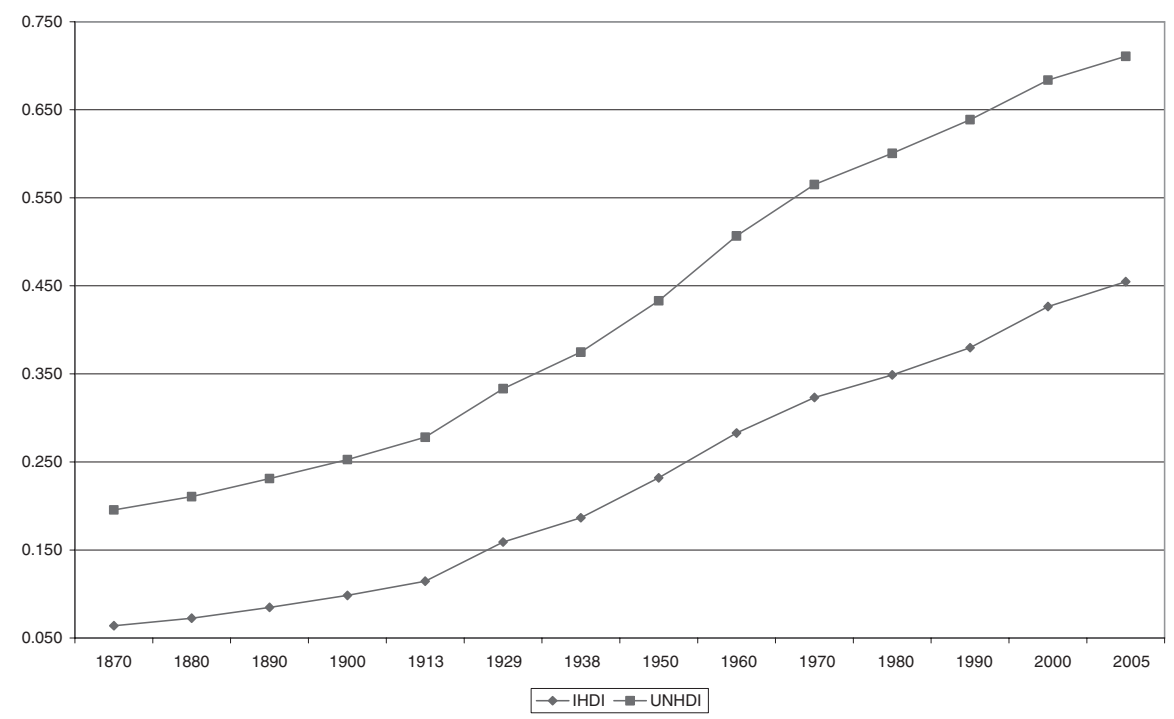

Figure 1. Human Development in the World, 1870-2005: UNHDI and IHDI Estimates.

1870-2005 the gain in the UNHDI represented almost two-thirds of its potential maximum (i.e. 1 less its initial level) whereas it was only two-fifths for the IHDI. Nonetheless, the UNHDI improvement was slower, at $0.9 \%$ yearly, against $1.4 \%$ for the IHDI.

Trends in world human development are affected by its regional evolution, particularly by that of large regions exhibiting idiosyncratic behaviour such as, for example, China and India or Africa. It can be noticed that their exclusion increases human development over 1870-2005 (Figure 2 and Table 2). However, while including Africa worsens the world level since 1950 and, especially, since 1990, in the case of China and India, from 1980 onwards, their inclusion has a less negative impact on the world level as they (and especially China) have experienced substantial gains in human development.

Regional disparities across the world seem, hence, relevant. Table 3 and Figure 3 compare levels and rates of change in the main regions. It appears that advanced countries, i.e. Western Europe and its offshoots (the USA, Canada, Australia and New Zealand) plus Japan - labelled here as OECD - crossed the 0.5 'medium level' threshold only in the 1950s, and are about to reach a 'high level' of human development (0.8). ${ }^{34}$ Central and Eastern Europe (including Russia) experienced an impressive catching up to the OECD between the 1920s and 1960, driven by Soviet Russia's gains in human development, to stagnate and diverge thereafter. Latin America, in turn, caught up to the OECD until the 1970s, although more intensively during the first half of the 20th century, and has only reached the 'medium level' lately. Asia, starting from low levels - similar to those of Africa 


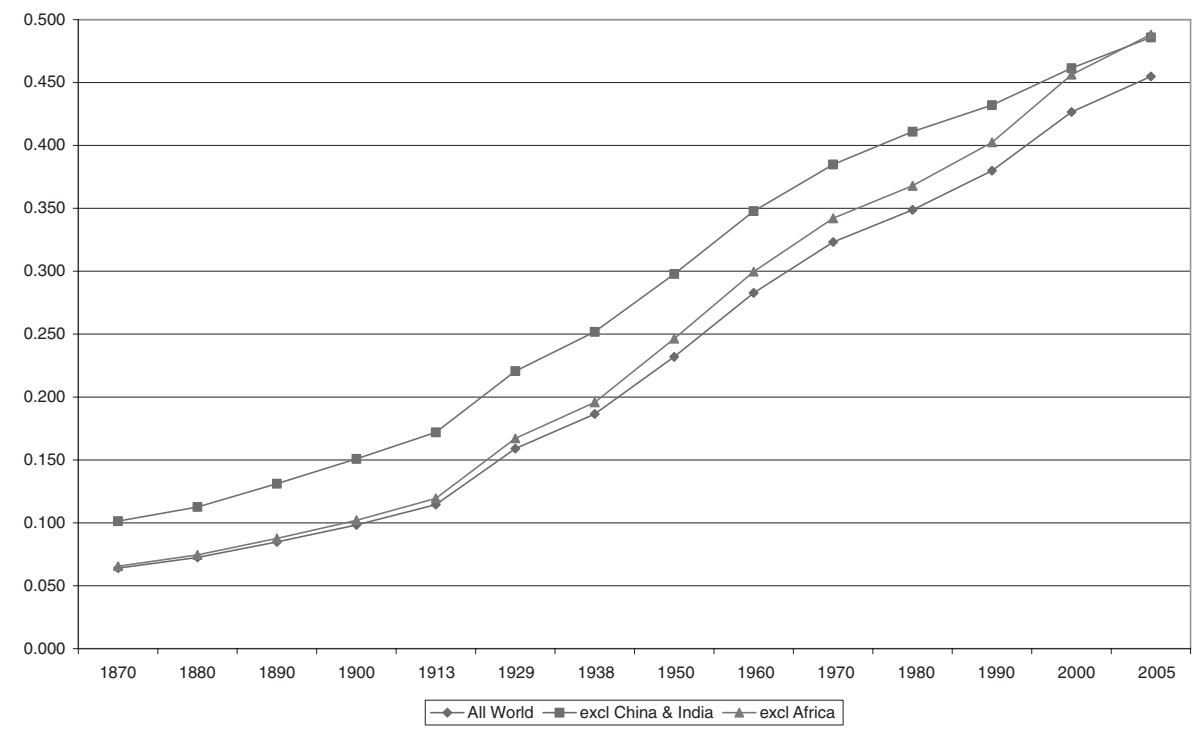

Figure 2. Human Development in the World, and excluding China and India and Africa, 1870-2005.

up to the early 1920s - improved significantly until 1970 and, again, at the turn of the century. A sustained improvement took place in Africa between the 1920s and the 1970 s - with special intensity in the 1930s and 1950s - but has slowed down since 1980. Thus, Asia's catching up and Eastern Europe's falling behind led these two regions to converge with Latin America, whereas Africa and the OECD tend to diverge at low and high levels of human development.

All this leads to the issue of whether the human development gap between the 'core' - OECD - and the 'periphery' - all other countries, labelled the Rest henceforth - deepened over time. I have carried out comparisons between OECD and the Rest in which China and India and Africa have been successively excluded (Table 4). It appears that the absolute gap - i.e. the difference in human development values - increased over time, although at a more intense pace until 1929 (Figure 4). The inclusion of either China and India or Africa increased the gap but, since the 1980s, the human development improvement in these Asian countries made the gap between OECD and the Rest, with and without China and India, converge. The absolute gap between 'core' and 'periphery' results from differentials between OECD and each of the components of the Rest. A closer look at different developing regions reveals that most of the OECD absolute gap with Latin America and Asia (excluding Japan) originated in the late 19th and the first half of the 20th century, becoming relatively stable since the 1950s. This is not the case, however, for the absolute gap between OECD and Africa which increased steadily throughout the 20th century, accelerating since 1980 (Figure 5). Central and Eastern 


\section{IMPROVING HUMAN DEVELOPMENT}

Table 2. Human Development in the World, and excluding China and India, and Africa, 1870-2005.

\begin{tabular}{|c|c|c|c|c|c|c|c|}
\hline \multirow[b]{2}{*}{ Panel A } & \multicolumn{3}{|c|}{ Levels } & \multirow[b]{2}{*}{ Panel B } & \multicolumn{3}{|c|}{ Annual growth rates } \\
\hline & All & $\begin{array}{l}\text { Excluding } \\
\text { China } \\
\text { and India }\end{array}$ & $\begin{array}{c}\text { Excluding } \\
\text { Africa }\end{array}$ & & All & $\begin{array}{l}\text { Excluding } \\
\text { China } \\
\text { and India }\end{array}$ & $\begin{array}{c}\text { Excluding } \\
\text { Africa }\end{array}$ \\
\hline 1870 & 0.064 & 0.101 & 0.066 & $1870-1880$ & 1.2 & 1.1 & 1.3 \\
\hline 1880 & 0.072 & 0.113 & 0.074 & $1880-1890$ & 1.6 & 1.5 & 1.6 \\
\hline 1890 & 0.085 & 0.131 & 0.088 & $1890-1900$ & 1.5 & 1.4 & 1.5 \\
\hline 1900 & 0.098 & 0.151 & 0.102 & $1900-1913$ & 1.2 & 1.0 & 1.2 \\
\hline 1913 & 0.115 & 0.172 & 0.119 & 1913-1929 & 2.1 & 1.6 & 2.1 \\
\hline 1929 & 0.159 & 0.221 & 0.167 & 1929-1938 & 1.8 & 1.5 & 1.8 \\
\hline 1938 & 0.187 & 0.252 & 0.196 & $1938-1950$ & 1.8 & 1.4 & 1.9 \\
\hline 1950 & 0.232 & 0.298 & 0.246 & $1950-1960$ & 2.0 & 1.6 & 2.0 \\
\hline 1960 & 0.283 & 0.348 & 0.300 & $1960-1970$ & 1.3 & 1.0 & 1.3 \\
\hline 1970 & 0.323 & 0.385 & 0.342 & 1970-1980 & 0.8 & 0.7 & 0.7 \\
\hline 1980 & 0.349 & 0.411 & 0.368 & 1980-1990 & 0.9 & 0.5 & 0.9 \\
\hline 1990 & 0.380 & 0.432 & 0.402 & 1990-2000 & 1.2 & 0.7 & 1.3 \\
\hline 2000 & 0.427 & 0.461 & 0.456 & $2000-2005$ & 1.3 & 1.0 & 1.4 \\
\hline \multirow[t]{7}{*}{2005} & 0.455 & 0.486 & 0.488 & & & & \\
\hline & & & & $1870-1913$ & 1.4 & 1.2 & 1.4 \\
\hline & & & & 1913-1950 & 1.9 & 1.5 & 2.0 \\
\hline & & & & $1950-1970$ & 1.7 & 1.3 & 1.6 \\
\hline & & & & 1970-1990 & 0.8 & 0.6 & 0.8 \\
\hline & & & & 1990-2005 & 1.2 & 0.8 & 1.3 \\
\hline & & & & $1870-2005$ & 1.5 & 1.2 & 1.5 \\
\hline
\end{tabular}

Europe represent an outlier, with its gap to OECD closing between 1929 and 1960 to widen dramatically thereafter, converging towards the OECD-Latin America gap.

However, in relative terms, the gap - namely, the ratio between OECD and the Rest - fell from 5.8 in 1900 to 2.4 in 1960 (and when China and India are excluded, from 4.1 in 1890 to 2.0 in 1960) and stabilized for the last half a century (Figure 6). The relative gap between OECD and each of the developing regions shrank over time, but while by mid-20th century the main reduction had already taken place in Latin America (from a ratio of 4.1 to 2 over 1880-1950, to represent 1.5 in 2005) and Asia (excluding Japan) (from 9.4 to 2.7 over 1913-1970, and was still 1.9 by 2005) to stabilizing thereafter, the gap between OECD and Africa declined more gradually over 1913-1980 (from 10.3 to 3.4, and remained at 3.2 in 2005). Meanwhile, the OECD gap with Eastern Europe (including Russia), after falling to a minimum by 1960 , provided the exception by increasing to return to its pre-World War II size (Figure 7). It is worth noting that the declining relative 
Table 3. Human Development across World Regions, 1870-2005.

\begin{tabular}{|c|c|c|c|c|c|c|}
\hline \multirow[b]{2}{*}{ Panel A } & \multicolumn{6}{|c|}{ Levels } \\
\hline & World & OECD & $\begin{array}{l}\text { Central and } \\
\text { and Eastern } \\
\text { Europe } \\
\text { (w/Russia) }\end{array}$ & $\begin{array}{c}\text { Latin } \\
\text { America }\end{array}$ & $\begin{array}{c}\text { Asia } \\
\text { (excluding } \\
\text { Japan) }\end{array}$ & Africa \\
\hline 1870 & 0.064 & 0.180 & 0.074 & 0.044 & 0.024 & 0.020 \\
\hline 1880 & 0.072 & 0.200 & 0.085 & 0.049 & 0.026 & 0.021 \\
\hline 1890 & 0.085 & 0.235 & 0.099 & 0.061 & 0.028 & 0.022 \\
\hline 1900 & 0.098 & 0.269 & 0.122 & 0.076 & 0.029 & 0.026 \\
\hline 1913 & 0.115 & 0.305 & 0.141 & 0.106 & 0.032 & 0.030 \\
\hline 1929 & 0.159 & 0.379 & 0.209 & 0.141 & 0.067 & 0.043 \\
\hline 1938 & 0.187 & 0.414 & 0.280 & 0.163 & 0.087 & 0.058 \\
\hline 1950 & 0.232 & 0.468 & 0.399 & 0.234 & 0.118 & 0.074 \\
\hline 1960 & 0.283 & 0.531 & 0.495 & 0.281 & 0.170 & 0.116 \\
\hline 1970 & 0.323 & 0.591 & 0.527 & 0.328 & 0.221 & 0.147 \\
\hline 1980 & 0.349 & 0.636 & 0.541 & 0.383 & 0.253 & 0.185 \\
\hline 1990 & 0.380 & 0.684 & 0.542 & 0.414 & 0.302 & 0.209 \\
\hline 2000 & 0.427 & 0.746 & 0.536 & 0.485 & 0.369 & 0.228 \\
\hline \multirow[t]{2}{*}{2005} & 0.455 & 0.779 & 0.557 & 0.510 & 0.406 & 0.245 \\
\hline & \multicolumn{6}{|c|}{ Average growth rates $(\%)$} \\
\hline Panel B & World & OECD & $\begin{array}{c}\text { Central and } \\
\text { and Eastern } \\
\text { Europe } \\
\text { (w/Russia) }\end{array}$ & $\begin{array}{c}\text { Latin } \\
\text { America }\end{array}$ & $\begin{array}{c}\text { Asia } \\
\text { (excluding } \\
\text { Japan) }\end{array}$ & Africa \\
\hline $1870-1880$ & 1.2 & 1.1 & 1.4 & 1.1 & 0.7 & 0.5 \\
\hline $1880-1890$ & 1.6 & 1.6 & 1.5 & 2.2 & 0.8 & 0.6 \\
\hline $1890-1900$ & 1.5 & 1.3 & 2.1 & 2.2 & 0.3 & 1.6 \\
\hline 1900-1913 & 1.2 & 1.0 & 1.1 & 2.6 & 0.8 & 0.9 \\
\hline 1913-1929 & 2.1 & 1.4 & 2.5 & 1.8 & 4.5 & 2.3 \\
\hline 1929-1938 & 1.8 & 1.0 & 3.3 & 1.6 & 2.9 & 3.4 \\
\hline $1938-1950$ & 1.8 & 1.0 & 2.9 & 3.0 & 2.6 & 2.0 \\
\hline 1950-1960 & 2.0 & 1.3 & 2.1 & 1.8 & 3.6 & 4.6 \\
\hline $1960-1970$ & 1.3 & 1.1 & 0.6 & 1.6 & 2.6 & 2.4 \\
\hline 1970-1980 & 0.8 & 0.7 & 0.3 & 1.5 & 1.3 & 2.3 \\
\hline 1980-1990 & 0.9 & 0.7 & 0.0 & 0.8 & 1.8 & 1.2 \\
\hline 1990-2000 & 1.2 & 0.9 & -0.1 & 1.6 & 2.0 & 0.9 \\
\hline 2000-2005 & 1.3 & 0.9 & 0.8 & 1.0 & 1.9 & 1.4 \\
\hline 1870-1913 & 1.4 & 1.2 & 1.5 & 2.1 & 0.7 & 0.9 \\
\hline 1913-1950 & 1.9 & 1.2 & 2.8 & 2.1 & 3.5 & 2.5 \\
\hline $1950-1970$ & 1.7 & 1.2 & 1.4 & 1.7 & 3.1 & 3.5 \\
\hline 1970-1990 & 0.8 & 0.7 & 0.1 & 1.2 & 1.6 & 1.8 \\
\hline 1990-2005 & 1.2 & 0.9 & 0.2 & 1.4 & 2.0 & 1.1 \\
\hline 1870-2005 & 1.5 & 1.1 & 1.5 & 1.8 & 2.1 & 1.9 \\
\hline
\end{tabular}




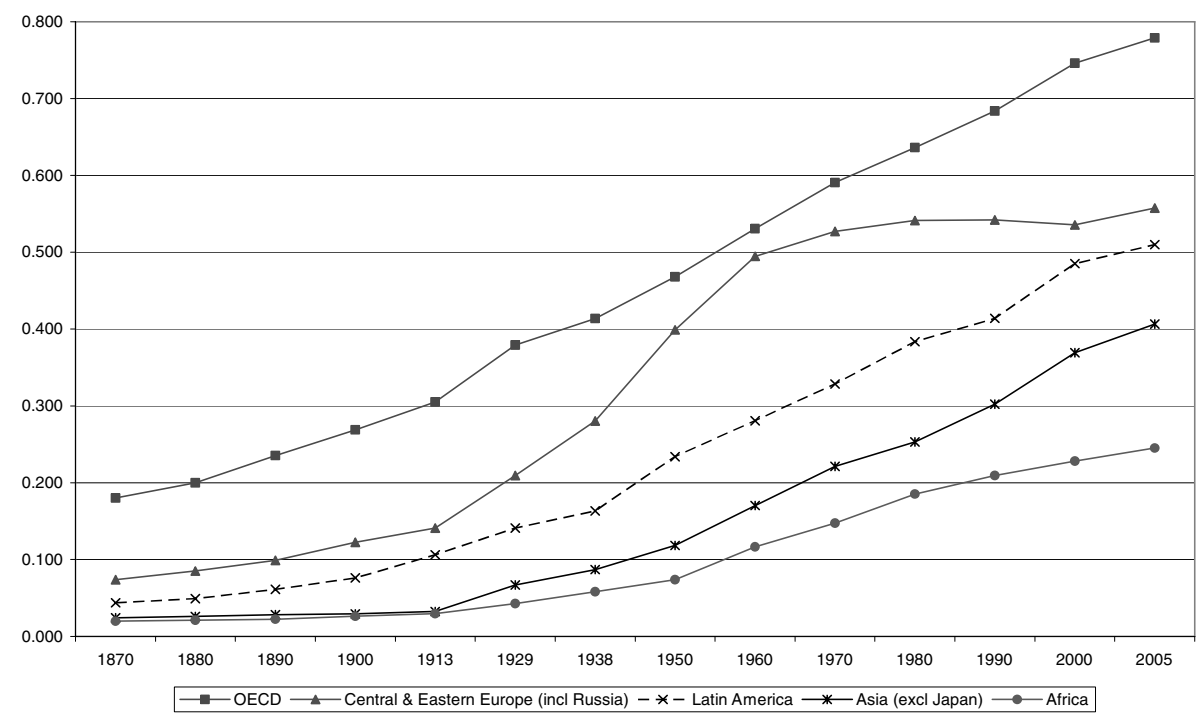

Figure 3. Human Development Across World Regions, 1870-2005.

gap in human development contrasts with the increasing gap in per capita income (Figure 8).

At this point it is worth focusing on how the absolute and relative differentials between OECD and the Rest resulting from the IHDI compare to those from the conventional UNHDI. Although the absolute gap is initially larger in the case of the UNHDI, it exhibits an early declining trend (since the late 1920s), against a steady widening gap for the IHDI (Figure 9). When the relative differential is considered, it is appears that the UNHDI gap is substantially lower and experienced a milder contraction over 1900-1960 (Figure 10). Thus, the UNHDI offers a more benign view of the core-periphery differentials than the new human development index.

And how does human development in today's developing countries compare to that of advanced nations in the past? By 2005, the level of human development in the Rest was similar to the OECD's in 1938, it had achieved the OECD level of 1913 by the mid-1980s, and only by the early 1950s matched the OECD level in 1870 (Table 4). A similar exercise for major world regions indicates that, in 2005, average human development levels in Central and Eastern Europe (including Russia), Latin America, Asia (excluding Japan) and Africa matched those of the OECD in 1965, 1955, 1938 and 1890, respectively. Alternatively, the OECD level of human development in 1913 was only reached by Central and Eastern Europe in the late 1940s, Latin America in 1965, Asia in 1990 and has not been achieved in Africa yet (Table 3). ${ }^{35}$

But, do regional differentials with the OECD in terms of human development match those in per capita GDP? In general, developing countries perform better in 
Table 4. Human Development in OECD and the Rest, 1870-2005.

\begin{tabular}{|c|c|c|c|c|c|c|c|c|c|}
\hline \multirow[b]{3}{*}{ Panel A } & \multicolumn{4}{|c|}{ Levels } & \multicolumn{5}{|c|}{ Annual growth rates } \\
\hline & \multirow[b]{2}{*}{ OECD } & \multirow[b]{2}{*}{$\begin{array}{l}\text { The } \\
\text { Rest }\end{array}$} & \multicolumn{2}{|c|}{$\begin{array}{l}\text { The Rest } \\
\text { without }\end{array}$} & \multirow[b]{2}{*}{ Panel B } & \multirow[b]{2}{*}{ OECD } & \multirow[b]{2}{*}{$\begin{array}{l}\text { The } \\
\text { Rest }\end{array}$} & \multicolumn{2}{|c|}{$\begin{array}{l}\text { The Rest } \\
\text { without }\end{array}$} \\
\hline & & & $\begin{array}{l}\text { China } \\
\text { and } \\
\text { India }\end{array}$ & Africa & & & & $\begin{array}{c}\text { China } \\
\text { and } \\
\text { India }\end{array}$ & Africa \\
\hline 1870 & 0.180 & 0.032 & 0.043 & 0.032 & $1870-1880$ & 1.1 & 1.1 & 1.3 & 1.2 \\
\hline 1880 & 0.200 & 0.036 & 0.049 & 0.036 & $1880-1890$ & 1.6 & 1.3 & 1.5 & 1.3 \\
\hline 1890 & 0.235 & 0.041 & 0.057 & 0.041 & $1890-1900$ & 1.3 & 1.4 & 1.9 & 1.4 \\
\hline 1900 & 0.269 & 0.046 & 0.069 & 0.048 & 1900-1913 & 1.0 & 1.3 & 1.5 & 1.4 \\
\hline 1913 & 0.305 & 0.055 & 0.083 & 0.057 & 1913-1929 & 1.4 & 3.2 & 2.4 & 3.3 \\
\hline 1929 & 0.379 & 0.093 & 0.122 & 0.097 & 1929-1938 & 1.0 & 3.0 & 2.9 & 3.0 \\
\hline 1938 & 0.414 & 0.121 & 0.158 & 0.127 & $1938-1950$ & 1.0 & 2.5 & 2.2 & 2.6 \\
\hline 1950 & 0.468 & 0.163 & 0.206 & 0.174 & 1950-1960 & 1.3 & 2.9 & 2.3 & 2.9 \\
\hline 1960 & 0.531 & 0.217 & 0.259 & 0.231 & 1960-1970 & 1.1 & 1.8 & 1.4 & 1.8 \\
\hline 1970 & 0.591 & 0.261 & 0.297 & 0.276 & 1970-1980 & 0.7 & 1.1 & 1.0 & 1.0 \\
\hline 1980 & 0.636 & 0.290 & 0.328 & 0.305 & 1980-1990 & 0.7 & 1.2 & 0.7 & 1.2 \\
\hline 1990 & 0.684 & 0.326 & 0.352 & 0.344 & $1990-2000$ & 0.9 & 1.4 & 0.7 & 1.5 \\
\hline 2000 & 0.746 & 0.374 & 0.380 & 0.400 & $2000-2005$ & 0.9 & 1.5 & 1.3 & 1.6 \\
\hline \multirow[t]{7}{*}{2005} & 0.779 & 0.404 & 0.405 & 0.434 & & & & & \\
\hline & & & & & $1870-1913$ & 1.2 & 1.3 & 1.5 & 1.3 \\
\hline & & & & & 1913-1950 & 1.2 & 2.9 & 2.4 & 3.0 \\
\hline & & & & & $1950-1970$ & 1.2 & 2.3 & 1.8 & 2.3 \\
\hline & & & & & 1970-1990 & 0.7 & 1.1 & 0.9 & 1.1 \\
\hline & & & & & 1990-2005 & 0.9 & 1.4 & 0.9 & 1.5 \\
\hline & & & & & $1870-2005$ & 1.1 & 1.9 & 1.7 & 1.9 \\
\hline
\end{tabular}

human development than in income per head terms - although not to the extent suggested by the conventional UNHDI (Crafts, 2002). Thus, in 2005, real per capita GDP for the Rest was similar to that of OECD by 1925, and only in 1970 did the Rest achieve the OECD income per head by 1870. Furthermore, in 2005, real per capita GDP in Latin America, Asia and Africa were similar to that of OECD by the early 1950s, 1920 and mid-19th century, respectively, whereas OECD income per head in 1913 was not reached in Latin America until the late 1960s, up to 2000 in Asia, and has still to be achieved in Africa. This is the result of the public provision of health (McKeown et al., 1975; McKinley and McKinley, 1977; Loudon, 2000; Cutler and Miller, 2005) and education that increased more than proportionally to income per head.

Trends in human development result from those exhibited by each of its dimensions. For the world as a whole, education is the dimension which fits IHDI evolution more closely, whereas life expectancy and adjusted income, with lower 


\section{IMPROVING HUMAN DEVELOPMENT}

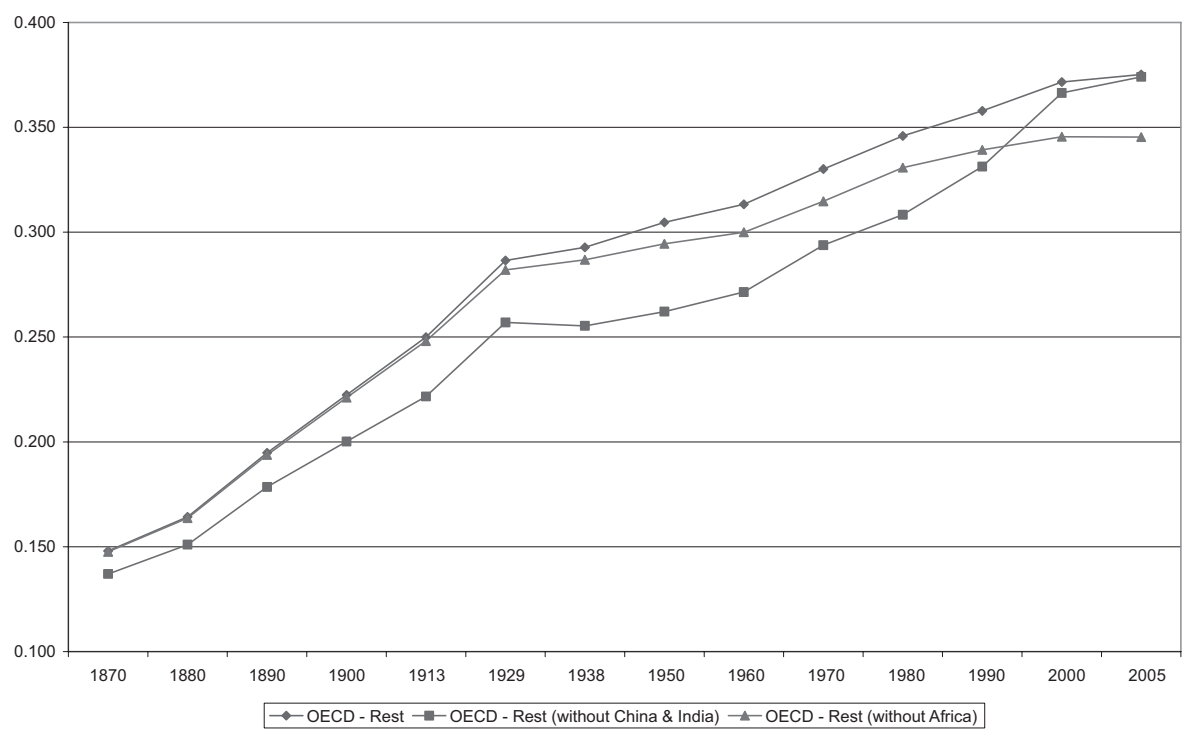

Figure 4. Absolute Gap in Human Development between OECD and the Rest, 1870-2005.

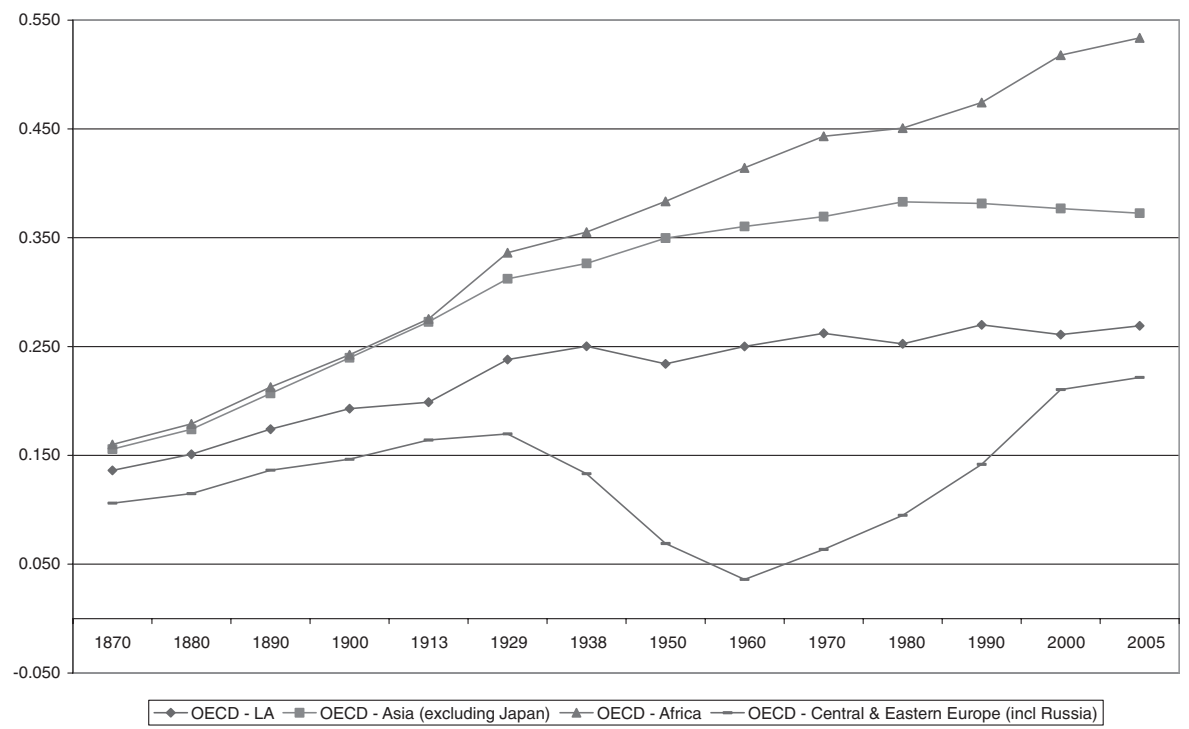

Figure 5. Absolute Gap in Human Development between OECD and Developing Regions. 


\section{ESCOSURA}

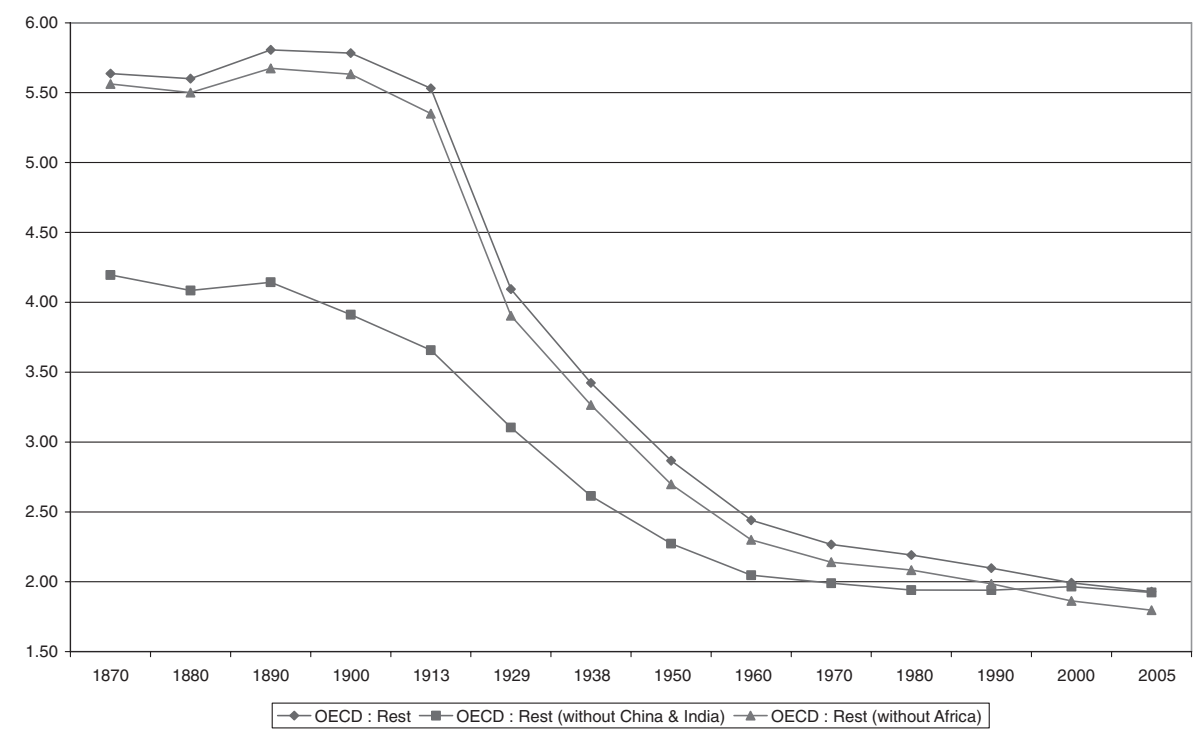

Figure 6. Relative Gap in Human Development between OECD and the Rest, 1870-2005.

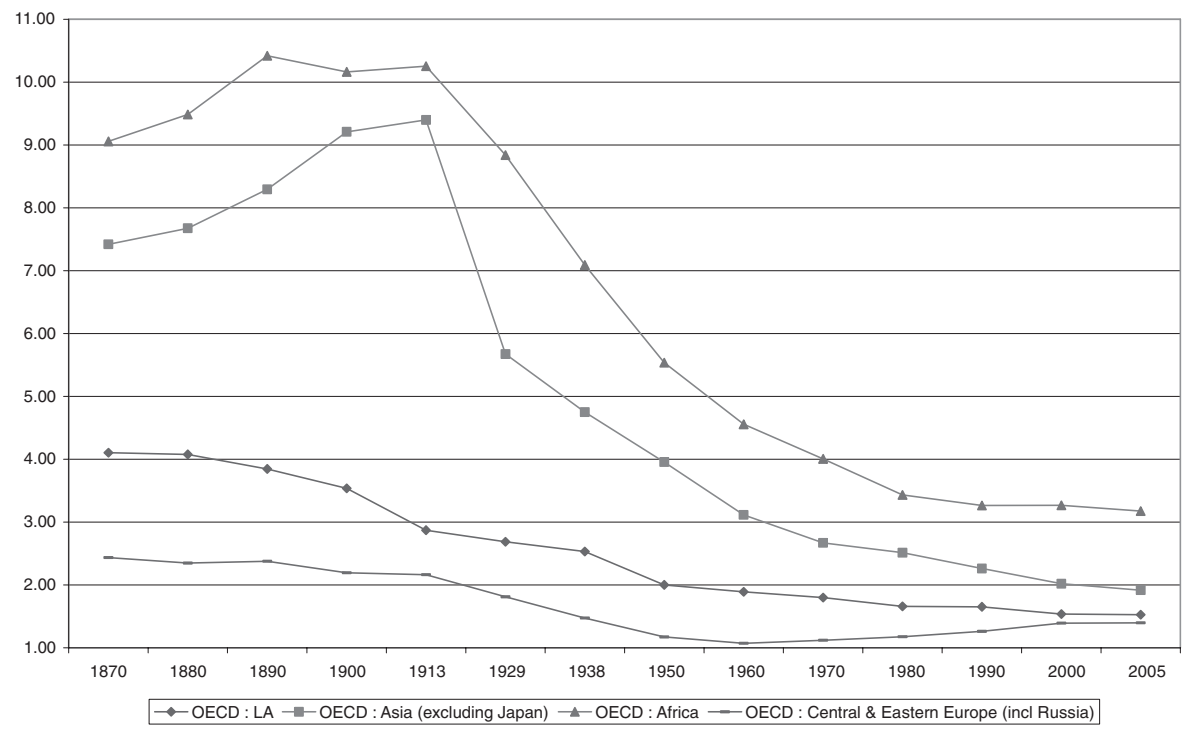

Figure 7. Relative Gap in Human Development between OECD and Developing Regions. 


\section{IMPROVING HUMAN DEVELOPMENT}

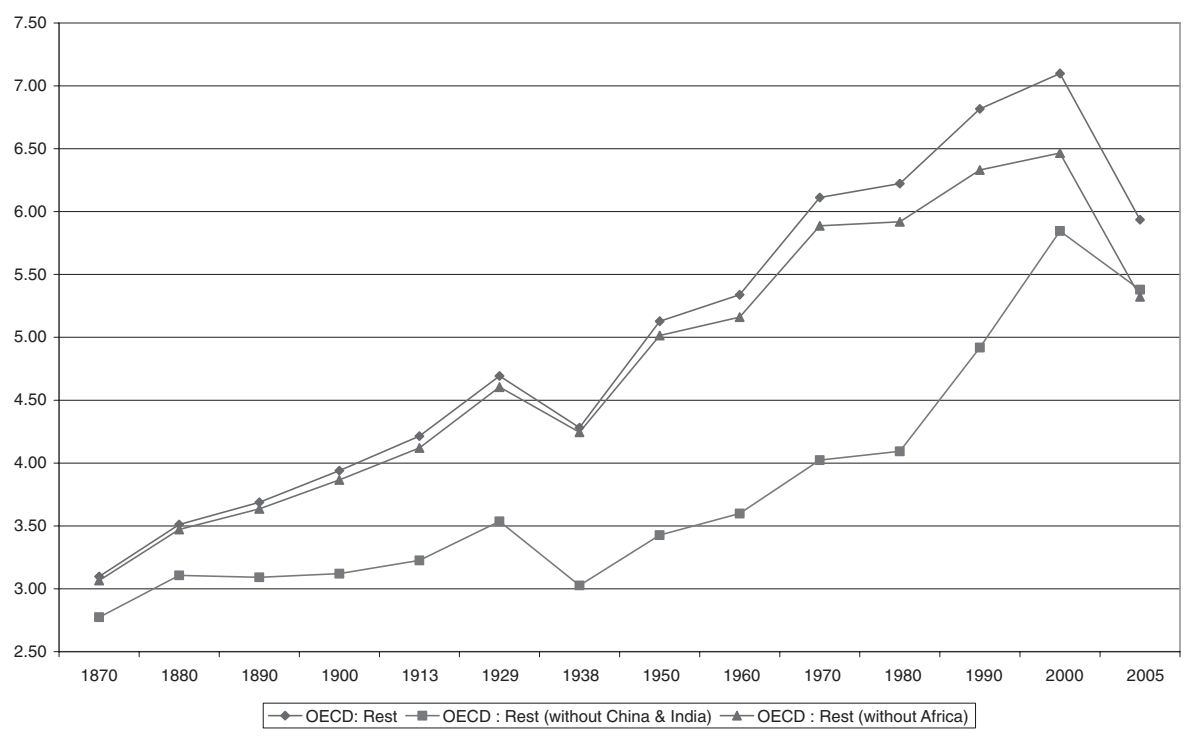

Figure 8. Relative Gap in Real Per Capita GDP between OECD and the Rest, 1870-2005.

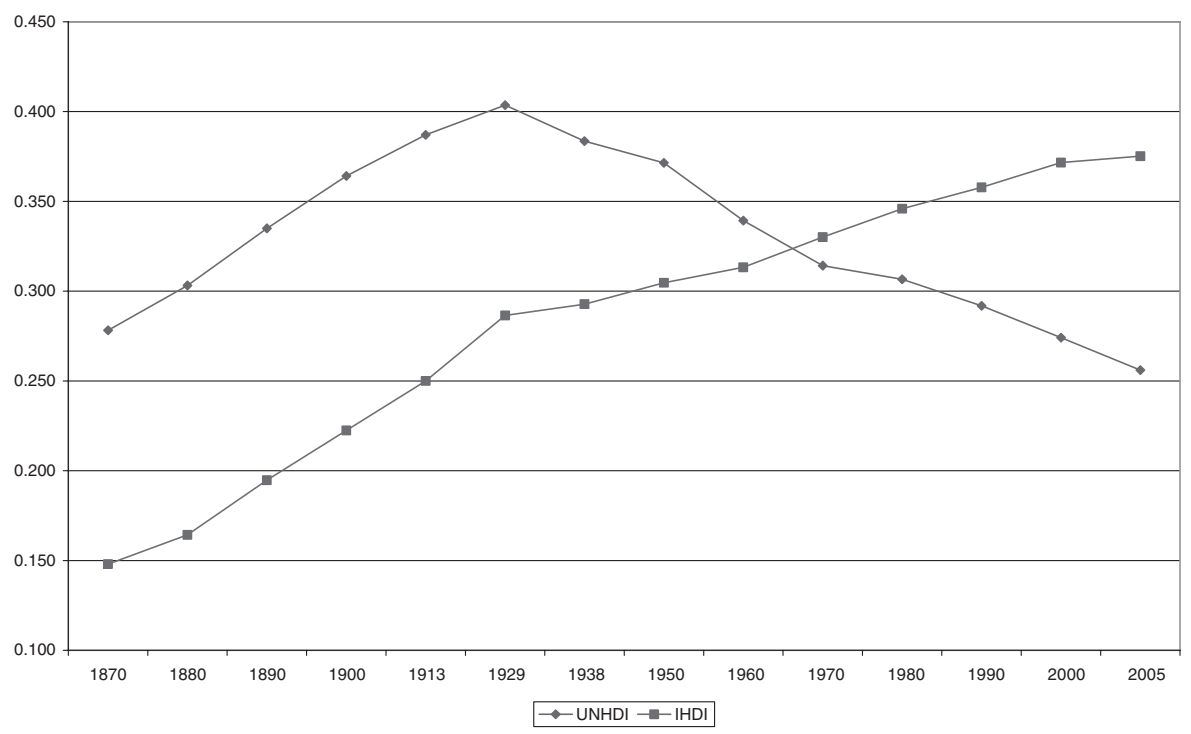

Figure 9. Absolute Human Development Gap between OECD and the Rest: UNHDI and IHDI. 


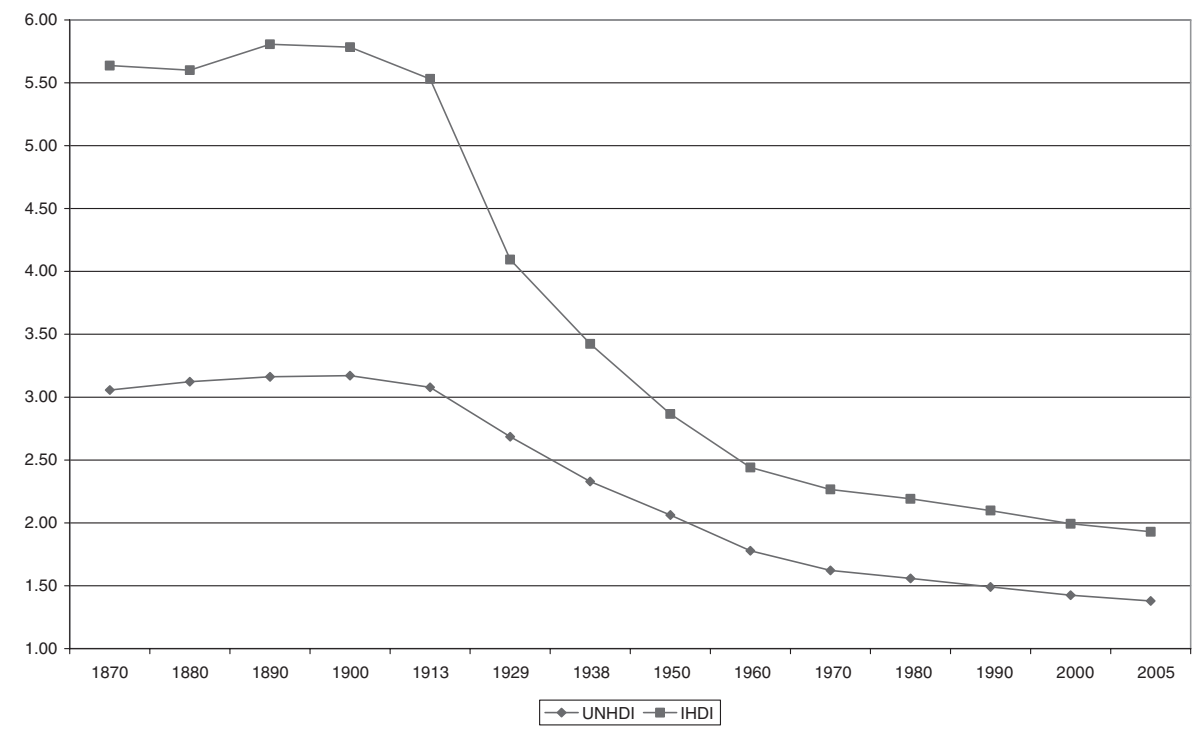

Figure 10. Relative Human Development Gap between OECD and the Rest: UNHDI and IHDI.

and higher initial levels, experience faster and slower improvements, respectively. Human development dimensions, thus, converge, and more intensely before 1970 (Figure 11 and Table 5, Panel A).

The multiplicative nature of the new human development index allow us to decompose changes in IHDI into those of its dimensions - i.e. the transformed values of life expectancy and education, and adjusted per capita income. Thus, expression (4) can be differentiated, and changes in the IHDI expressed as the equally weighted average of the variation rates of its components. Thus, denoting rates of variation as lower case,

$$
\mathrm{IHDI}=1 / 3 l+1 / 3 e+1 / 3 y_{\mathrm{un}}
$$

It can be observed that gains in the IHDI are driven by improvements in its social indicators (Table 5, Panel B, and Figure 12). Life expectancy is the main contributor to improving world human development over the long run, and specifically between 1880 and 1990. This fact is associated with the diffusion of new methods of preventing the disease transmission, including low cost improvements in public health and knowledge dissemination through schooling (Riley, 2005a) and to the introduction of new vaccines (since the 1890s) and drugs to cure infectious diseases (sulpha drugs since the late 1930s and, since the 1950s, antibiotics) (Easterlin, 1999, p. 270; Jayachandran et al., 2010). A closer look highlights the contribution of education prior to 1913 and, again, since 1990 . 


\section{IMPROVING HUMAN DEVELOPMENT}

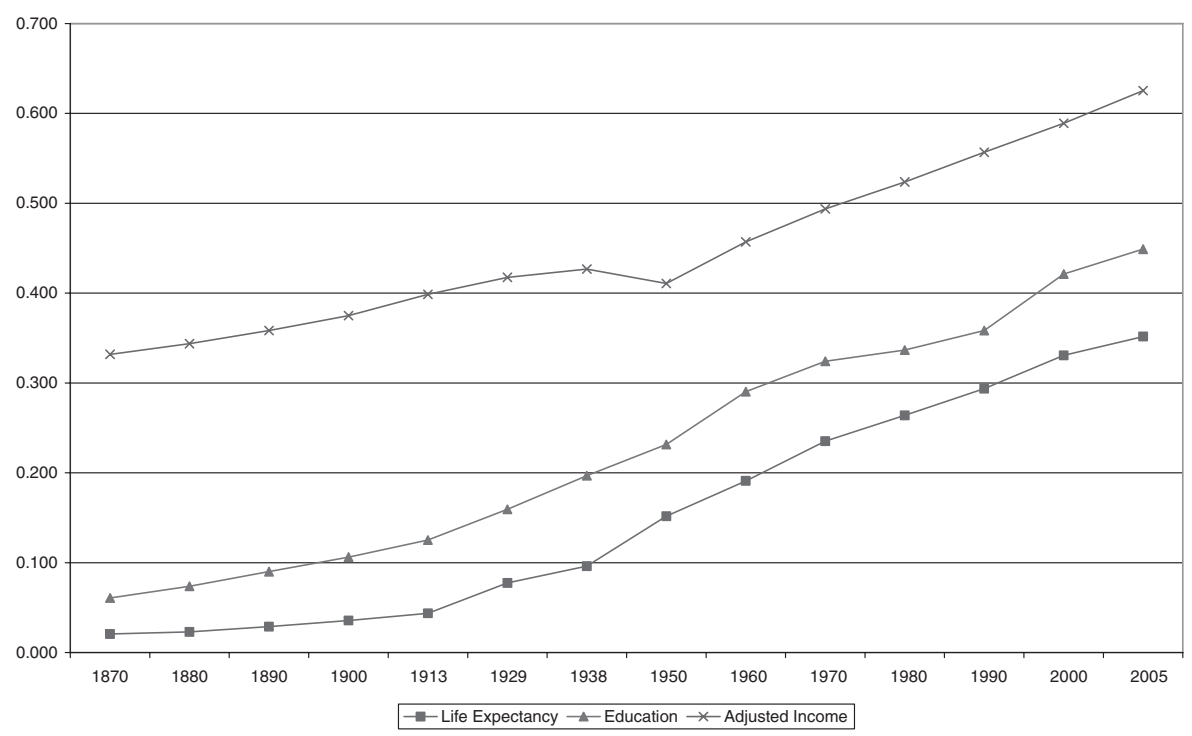

Figure 11. Dimensions of Human Development in the World, 1870-2005.

Table 5. Human Development and Its Dimensions: the World, 1870-2005.

\begin{tabular}{|c|c|c|c|c|c|c|c|c|c|}
\hline \multirow[b]{2}{*}{ Panel A } & \multicolumn{4}{|c|}{ Levels } & \multirow[b]{2}{*}{ Panel B } & \multicolumn{4}{|c|}{$\begin{array}{c}\text { Annual IHDI growth and its } \\
\text { decomposition }(\%)\end{array}$} \\
\hline & IHDI & $\begin{array}{c}\text { Life } \\
\text { expectancy }\end{array}$ & Education & $\begin{array}{l}\text { Adjusted } \\
\text { income }\end{array}$ & & IHDI & $\begin{array}{c}\text { Life } \\
\text { expectancy }\end{array}$ & Education & $\begin{array}{l}\text { Adjusted } \\
\text { income }\end{array}$ \\
\hline 1870 & 0.064 & 0.021 & 0.061 & 0.332 & $1870-1880$ & 1.2 & 0.32 & 0.58 & 0.10 \\
\hline 1880 & 0.072 & 0.023 & 0.074 & 0.344 & 1880-1890 & 1.6 & 0.49 & 0.42 & 0.09 \\
\hline 1890 & 0.085 & 0.029 & 0.090 & 0.358 & 1890-1900 & 1.5 & 0.50 & 0.39 & 0.11 \\
\hline 1900 & 0.098 & 0.036 & 0.106 & 0.375 & 1900-1913 & 1.2 & 0.47 & 0.38 & 0.14 \\
\hline 1913 & 0.115 & 0.044 & 0.125 & 0.399 & 1913-1929 & 2.1 & 0.67 & 0.28 & 0.05 \\
\hline 1929 & 0.159 & 0.077 & 0.159 & 0.418 & 1929-1938 & 1.8 & 0.48 & 0.47 & 0.05 \\
\hline 1938 & 0.187 & 0.096 & 0.197 & 0.427 & 1938-1950 & 1.8 & 0.79 & 0.28 & -0.07 \\
\hline 1950 & 0.232 & 0.152 & 0.232 & 0.411 & $1950-1960$ & 2.0 & 0.41 & 0.40 & 0.19 \\
\hline 1960 & 0.283 & 0.191 & 0.290 & 0.457 & 1960-1970 & 1.3 & 0.53 & 0.28 & 0.19 \\
\hline 1970 & 0.323 & 0.235 & 0.324 & 0.494 & 1970-1980 & 0.8 & 0.54 & 0.18 & 0.28 \\
\hline 1980 & 0.349 & 0.264 & 0.337 & 0.524 & 1980-1990 & 0.9 & 0.46 & 0.27 & 0.27 \\
\hline 1990 & 0.380 & 0.294 & 0.358 & 0.557 & 1990-2000 & 1.2 & 0.35 & 0.48 & 0.17 \\
\hline 2000 & 0.427 & 0.331 & 0.421 & 0.589 & 2000-2005 & 1.3 & 0.33 & 0.34 & 0.32 \\
\hline \multirow[t]{7}{*}{2005} & 0.455 & 0.352 & 0.449 & 0.625 & & & & & \\
\hline & & & & & 1870-1913 & 1.4 & 0.45 & 0.44 & 0.11 \\
\hline & & & & & 1913-1950 & 1.9 & 0.66 & 0.33 & 0.02 \\
\hline & & & & & 1950-1970 & 1.7 & 0.46 & 0.35 & 0.19 \\
\hline & & & & & 1970-1990 & 0.8 & 0.50 & 0.23 & 0.27 \\
\hline & & & & & 1990-2005 & 1.2 & 0.35 & 0.43 & 0.22 \\
\hline & & & & & $1870-2005$ & 1.5 & 0.52 & 0.37 & 0.12 \\
\hline
\end{tabular}




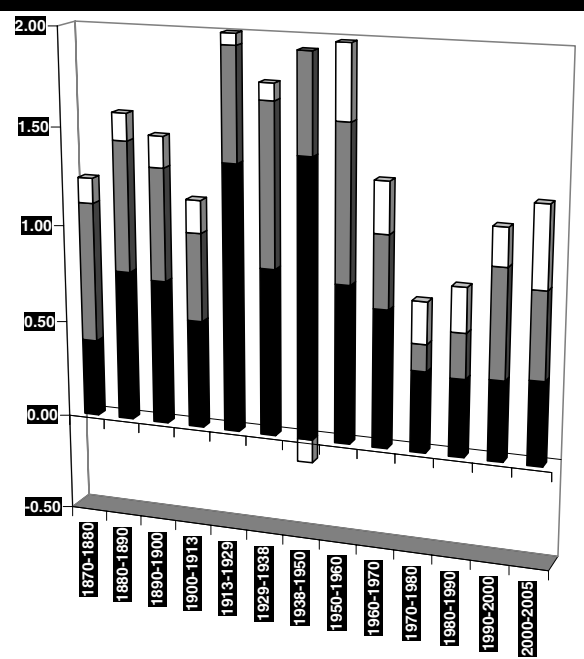

- Life Expectancy $\square$ Education $\square$ Adjusted Income

Figure 12. Decomposing IHDI Average Yearly Variation into its Dimensions in the World.

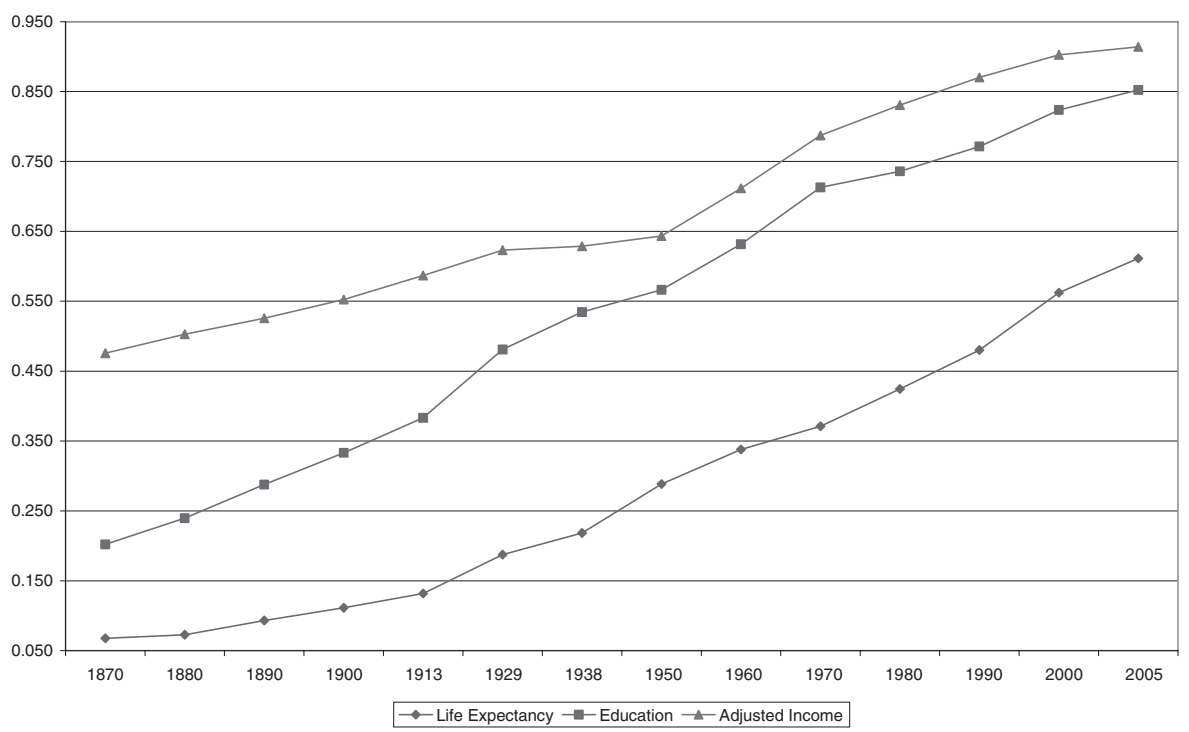

Figure 13. Dimensions of Human Development in the OECD, 1870-2005. 


\section{IMPROVING HUMAN DEVELOPMENT}

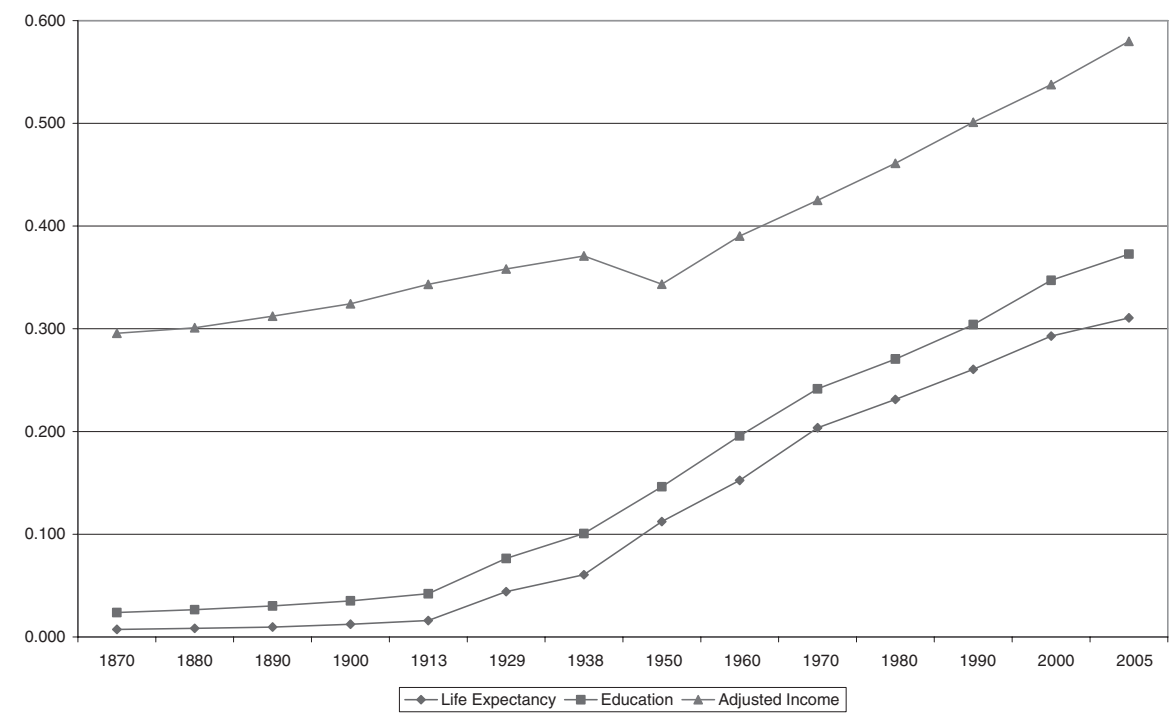

Figure 14. Dimensions of Human Development in the Rest, 1870-2005.

Table 6. Human Development and its Dimensions: OECD, 1870-2005.

\begin{tabular}{|c|c|c|c|c|c|c|c|c|c|}
\hline \multirow[b]{2}{*}{ Panel A } & \multicolumn{4}{|c|}{ Levels } & \multirow[b]{2}{*}{ Panel B } & \multicolumn{4}{|c|}{$\begin{array}{l}\text { Annual IHDI growth and its } \\
\text { decomposition }\end{array}$} \\
\hline & IHDI & $\begin{array}{c}\text { Life } \\
\text { expectancy }\end{array}$ & Education & $\begin{array}{l}\text { Adjusted } \\
\text { income }\end{array}$ & & IHDI & $\begin{array}{c}\text { Life } \\
\text { expectancy }\end{array}$ & Education & $\begin{array}{l}\text { Adjusted } \\
\text { income }\end{array}$ \\
\hline 1870 & 0.180 & 0.068 & 0.202 & 0.476 & $1870-1880$ & 1.1 & 0.25 & 0.57 & 0.19 \\
\hline 1880 & 0.200 & 0.073 & 0.240 & 0.503 & $1880-1890$ & 1.6 & 0.52 & 0.39 & 0.09 \\
\hline 1890 & 0.235 & 0.093 & 0.288 & 0.526 & $1890-1900$ & 1.3 & 0.48 & 0.39 & 0.13 \\
\hline 1900 & 0.269 & 0.111 & 0.333 & 0.553 & $1900-1913$ & 1.0 & 0.46 & 0.38 & 0.16 \\
\hline 1913 & 0.305 & 0.132 & 0.383 & 0.587 & 1913-1929 & 1.4 & 0.55 & 0.36 & 0.09 \\
\hline 1929 & 0.379 & 0.188 & 0.481 & 0.623 & 1929-1938 & 1.0 & 0.57 & 0.40 & 0.03 \\
\hline 1938 & 0.414 & 0.218 & 0.535 & 0.629 & $1938-1950$ & 1.0 & 0.77 & 0.16 & 0.06 \\
\hline 1950 & 0.468 & 0.288 & 0.566 & 0.643 & $1950-1960$ & 1.3 & 0.43 & 0.30 & 0.27 \\
\hline 1960 & 0.531 & 0.338 & 0.632 & 0.712 & $1960-1970$ & 1.1 & 0.30 & 0.38 & 0.32 \\
\hline 1970 & 0.591 & 0.371 & 0.713 & 0.787 & 1970-1980 & 0.7 & 0.61 & 0.14 & 0.24 \\
\hline 1980 & 0.636 & 0.424 & 0.736 & 0.831 & 1980-1990 & 0.7 & 0.57 & 0.22 & 0.21 \\
\hline 1990 & 0.684 & 0.480 & 0.771 & 0.870 & 1990-2000 & 0.9 & 0.61 & 0.25 & 0.14 \\
\hline 2000 & 0.746 & 0.562 & 0.824 & 0.903 & $2000-2005$ & 0.9 & 0.64 & 0.26 & 0.10 \\
\hline \multirow[t]{7}{*}{2005} & 0.779 & 0.611 & 0.852 & 0.914 & & & & & \\
\hline & & & & & $1870-1913$ & 1.2 & 0.44 & 0.42 & 0.14 \\
\hline & & & & & $1913-1950$ & 1.2 & 0.62 & 0.31 & 0.07 \\
\hline & & & & & $1950-1970$ & 1.2 & 0.37 & 0.34 & 0.30 \\
\hline & & & & & 1970-1990 & 0.7 & 0.59 & 0.18 & 0.23 \\
\hline & & & & & 1990-2005 & 0.9 & 0.62 & 0.26 & 0.13 \\
\hline & & & & & $1870-2005$ & 1.1 & 0.51 & 0.34 & 0.15 \\
\hline
\end{tabular}




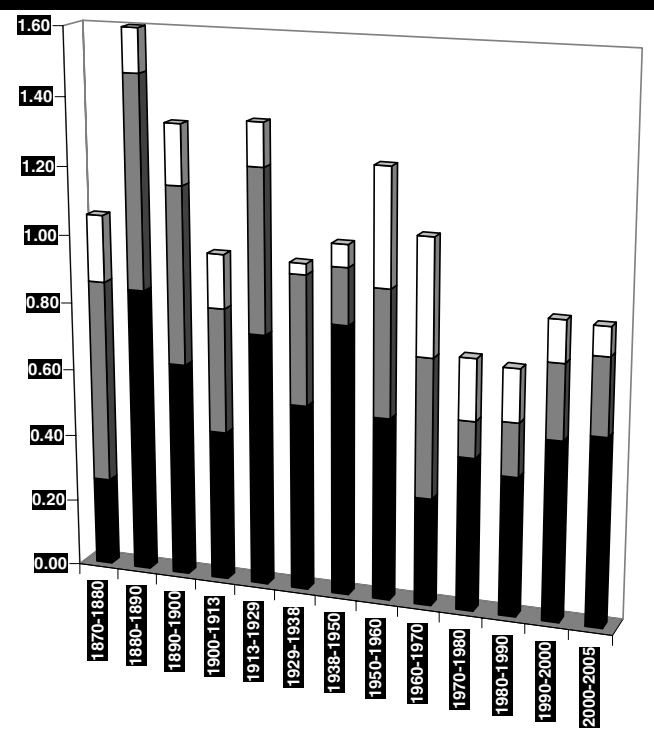

- Life Expectancy $\square$ Education $\square$ Adjusted Income

Figure 15. Decomposing IHDI Average Yearly Variation into its Dimensions in OECD.

When a similar exercise is carried out for the advanced and the developing countries and IHDI is decomposed into its dimensions (Figures 13 and 14), it emerges that, in the OECD, life expectancy made a significant contribution to the improvement of human development, especially during the first half of the 20th century and since 1970 (Table 6 and Figure 15). Also education did it in the late 19th and early 20th century and, again, in the 1960s. Meanwhile, in the Rest, education improvement was significant in the late 19th century and during the 1930s and, once more, since 1990; increasing longevity, however, only represented the main contribution to human development gains between 1913 and 1950 (even if it weakened during the Great Depression) (Table 7 and Figure 16). The stagnation of life expectancy in Eastern Europe, especially in Russia, since 1960 (and its decline in the 1990s), which converged to Asian levels, together with the remarkable slowdown since 1990 in Africa, as a result of HIV/AIDS, helps to explain it (Figure 17). Meanwhile, wide differences in education between Central and Eastern Europe and the developing world persisted over time (Figure 18).

In our previous discussion it was found that the human development gap between OECD and the Rest increased in absolute terms over the long run, whereas the opposite occurred in relative terms, but what role did each of its different dimensions play in it? In absolute terms, up to 1929, the larger gap was in terms 
Table 7. Human Development and its Dimensions: the Rest, 1870-2005.

\begin{tabular}{|c|c|c|c|c|c|c|c|c|c|}
\hline \multirow[b]{2}{*}{ Panel A } & \multicolumn{4}{|c|}{ Levels } & \multirow[b]{2}{*}{ Panel B } & \multicolumn{4}{|c|}{$\begin{array}{l}\text { Annual IHDI growth and its } \\
\text { decomposition }\end{array}$} \\
\hline & IHDI & $\begin{array}{c}\text { Life } \\
\text { expectancy }\end{array}$ & Education & $\begin{array}{l}\text { Adjusted } \\
\text { income }\end{array}$ & & IHDI & $\begin{array}{c}\text { Life } \\
\text { expectancy }\end{array}$ & Education & $\begin{array}{c}\text { Adjusted } \\
\text { income }\end{array}$ \\
\hline 1870 & 0.032 & 0.007 & 0.024 & 0.296 & $1870-1880$ & 1.1 & 0.48 & 0.45 & 0.07 \\
\hline 1880 & 0.036 & 0.008 & 0.027 & 0.301 & $1880-1890$ & 1.3 & 0.47 & 0.41 & 0.12 \\
\hline 1890 & 0.041 & 0.010 & 0.030 & 0.312 & $1890-1900$ & 1.4 & 0.57 & 0.34 & 0.09 \\
\hline 1900 & 0.046 & 0.013 & 0.035 & 0.324 & 1900-1913 & 1.3 & 0.51 & 0.37 & 0.12 \\
\hline 1913 & 0.055 & 0.016 & 0.042 & 0.343 & 1913-1929 & 3.2 & 0.61 & 0.36 & 0.03 \\
\hline 1929 & 0.093 & 0.044 & 0.076 & 0.358 & 1929-1938 & 3.0 & 0.50 & 0.44 & 0.06 \\
\hline 1938 & 0.121 & 0.061 & 0.101 & 0.371 & 1938-1950 & 2.5 & 0.68 & 0.41 & -0.08 \\
\hline 1950 & 0.163 & 0.112 & 0.146 & 0.343 & 1950-1960 & 2.9 & 0.42 & 0.40 & 0.18 \\
\hline 1960 & 0.217 & 0.152 & 0.196 & 0.390 & 1960-1970 & 1.8 & 0.49 & 0.36 & 0.15 \\
\hline 1970 & 0.261 & 0.204 & 0.242 & 0.425 & 1970-1980 & 1.1 & 0.40 & 0.35 & 0.25 \\
\hline 1980 & 0.290 & 0.231 & 0.271 & 0.461 & 1980-1990 & 1.2 & 0.37 & 0.37 & 0.26 \\
\hline 1990 & 0.326 & 0.261 & 0.304 & 0.501 & 1990-2000 & 1.4 & 0.37 & 0.41 & 0.22 \\
\hline 2000 & 0.374 & 0.293 & 0.347 & 0.538 & 2000-2005 & 1.5 & 0.29 & 0.35 & 0.37 \\
\hline \multirow[t]{7}{*}{2005} & 0.404 & 0.311 & 0.373 & 0.580 & & & & & \\
\hline & & & & & $1870-1913$ & 1.3 & 0.51 & 0.38 & 0.10 \\
\hline & & & & & 1913-1950 & 2.9 & 0.61 & 0.39 & 0.00 \\
\hline & & & & & 1950-1970 & 2.3 & 0.45 & 0.38 & 0.16 \\
\hline & & & & & 1970-1990 & 1.1 & 0.38 & 0.36 & 0.26 \\
\hline & & & & & 1990-2005 & 1.4 & 0.34 & 0.39 & 0.28 \\
\hline & & & & & $1870-2005$ & 1.9 & 0.52 & 0.38 & 0.09 \\
\hline
\end{tabular}

of education; then, life expectancy took over doubling its gap over 1929-2005 (Figure 19). In relative terms, a dramatic contraction in the life expectancy gap took place between 1913 and 1970 - especially during the first half of the 20th century - which then stagnated and only increased slightly since 1990, as a result of the growing OECD differential with Russia and Africa. The relative gap in education fell throughout the 20th century and at a remarkable pace over 1929-1960. In turn, the adjusted income gap, which arguably captures any other dimension of well-being, remained flat (Figure 20).

If we now try to ascertain which share in the reduction of the relative gap in human development between the OECD and the Rest is attributable to each of its dimensions, it appears that, during the phase of deeper decline, 1913-1960, although life expectancy accounted for most of it over 1913-1929 and 1938-1950, education was the main dimension responsible during the Depression years and in the 1950s. Since 1970, closing the gap slowed down, with education as the leading contributor (Figure 21). It can be suggested, therefore, that the human development gap between OECD and the Rest has not closed as the catching up in life expectancy has stopped, largely due to the behaviour of Russia and Africa, although it has weakened in terms of education. 


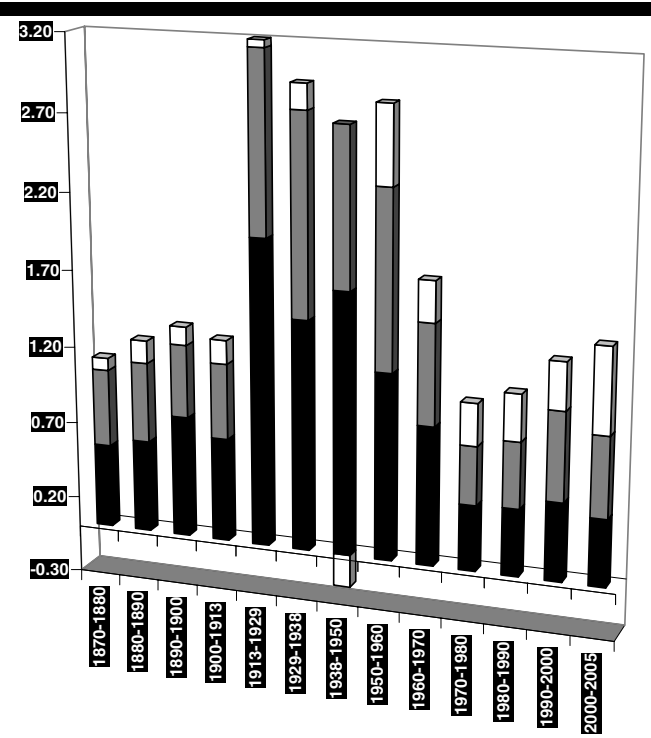

QLife Expectancy $\square$ Education $\square$ Adjusted Income

Figure 16. Decomposing IHDI Average Yearly Variation into its Dimensions in the Rest.

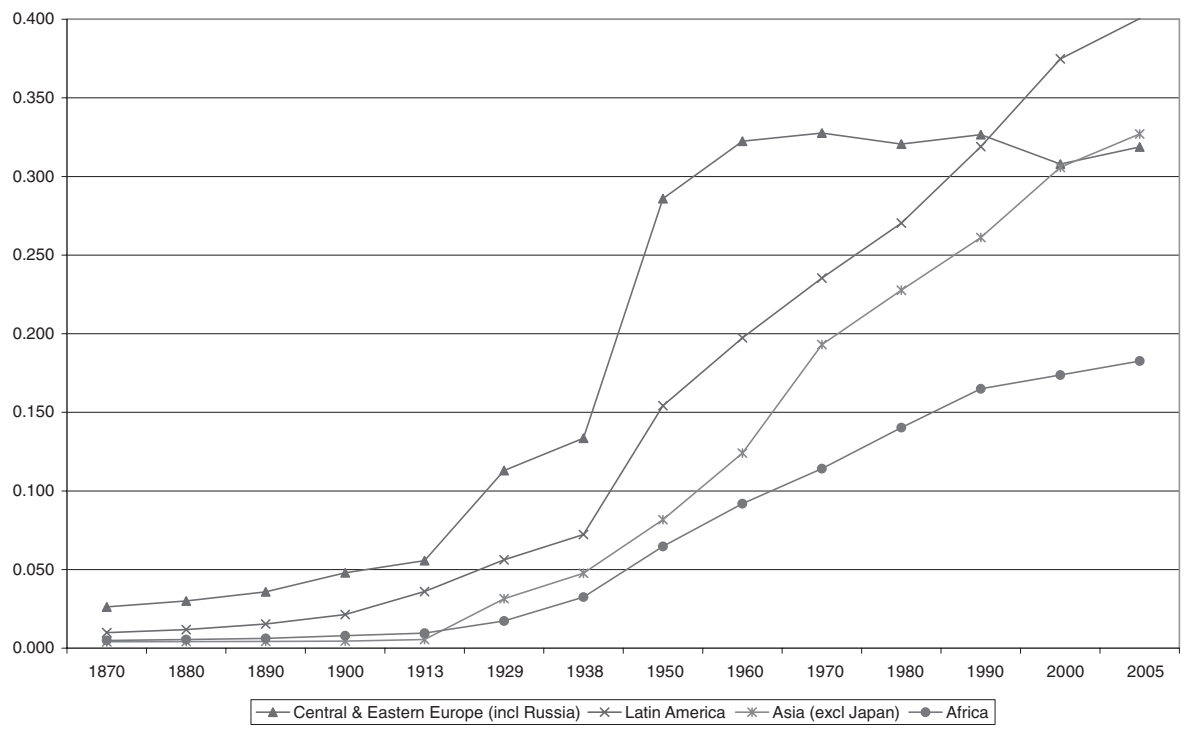

Figure 17. Life Expectancy in the Rest: Regional Composition. 


\section{IMPROVING HUMAN DEVELOPMENT}

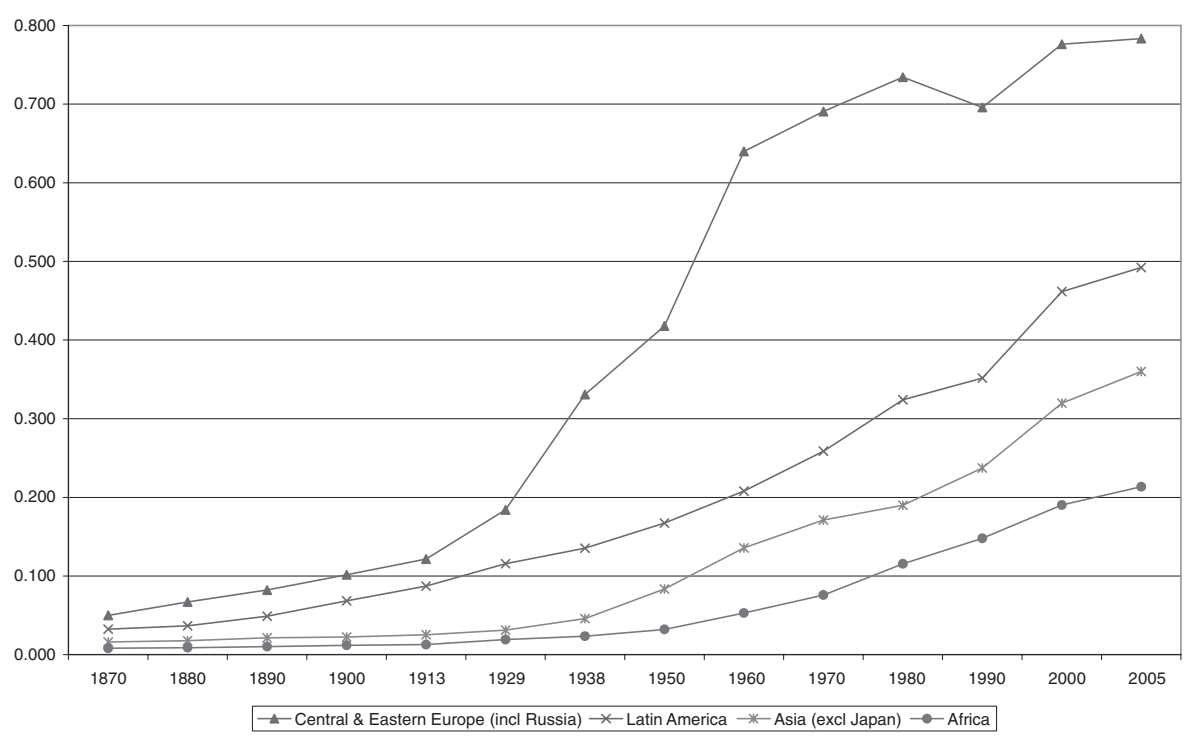

Figure 18. Education in the Rest: Regional Composition.

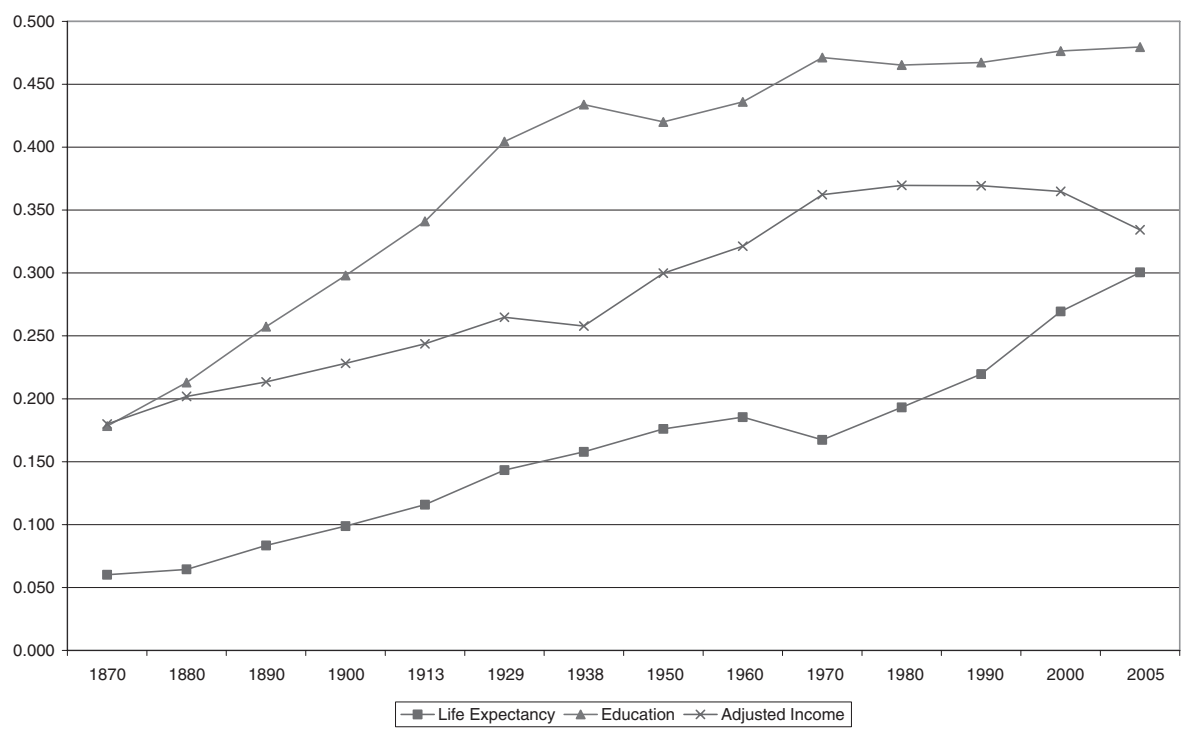

Figure 19. Human Development Dimensions: Absolute Gap between OECD and the Rest. 
ESCOSURA

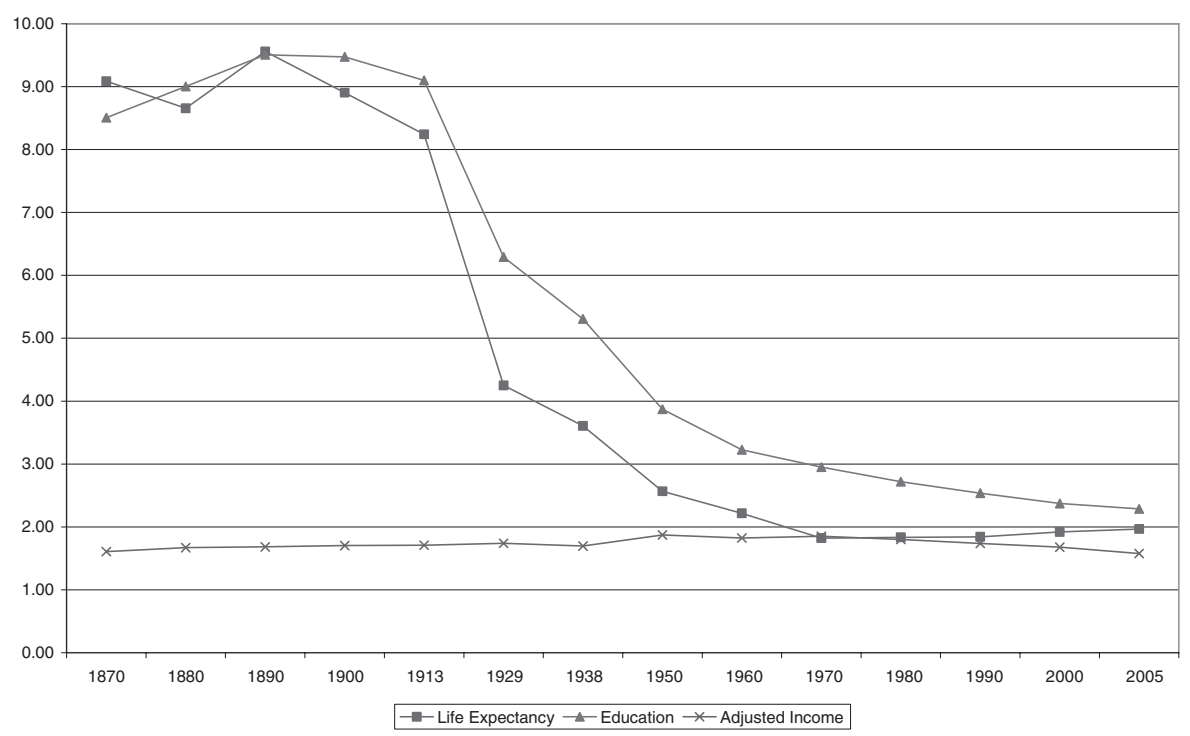

Figure 20. Human Development Dimensions: Relative Gap between OECD and the Rest.

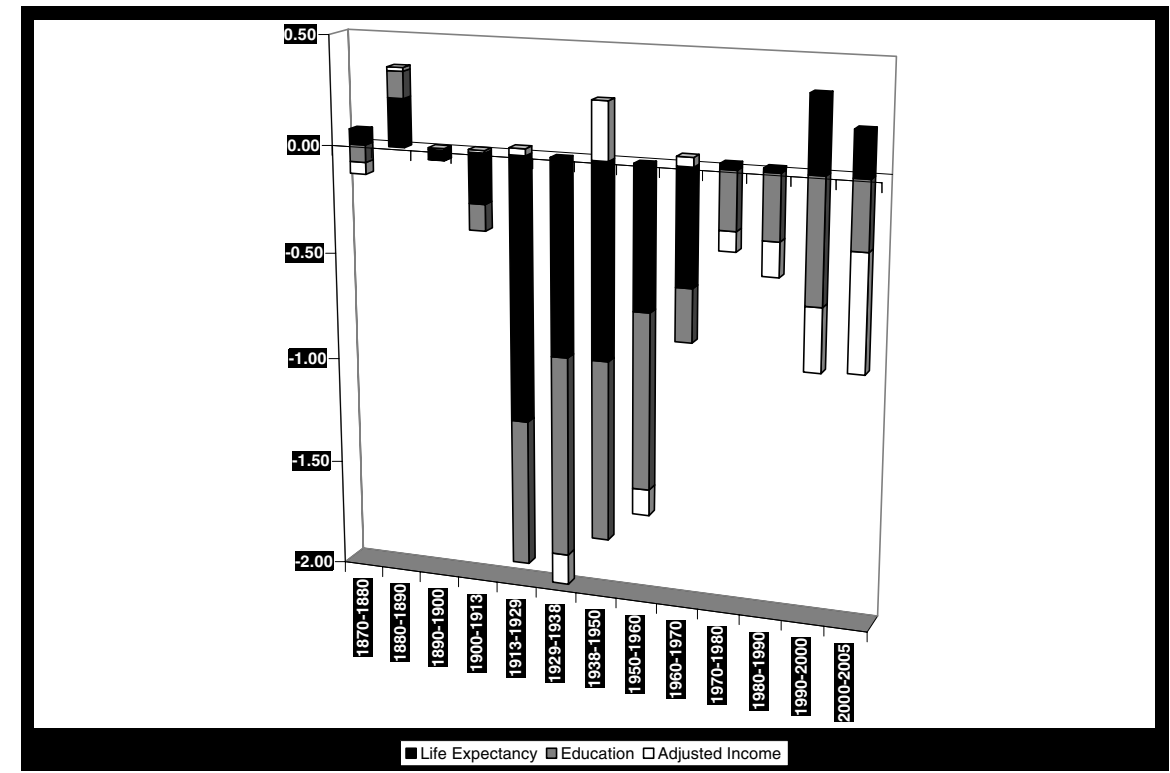

Figure 21. Decomposing Average Yearly Variation in the Relative OECD-Rest IHDI Gap into its Dimensions. 


\section{Concluding Remarks}

For many developing countries the usual pessimistic overtones of the Human Development Reports are contradicted by the rosy picture that emerges from their figures when compared with their own economic growth record. In an attempt to explain such a contradiction this paper offers a new IHDI in which social dimensions are obtained using a convex achievement function and the index's dimensions are combined multiplicatively.

A long-run improvement in world human development is found for the last 135 years that, nonetheless, fell short of its maximum potential. Regional variance emerges an important feature of human development. In particular, although the absolute gap between rich and poor countries widened, the relative gap in human development, contrary to the observed trend in real income per head, fell over time. However, closing the gap has slowed down its pace significantly since 1970 due to the behaviour of Africa and Central and Eastern Europe, especially Russia. Gains in life expectancy provide the main contribution to improving human development over the long run. However, the gap has failed to close largely as a result of the stagnation of life expectancy in Russia since 1960 and more recently as a consequence of the impact of HIV/AIDS in Sub-Saharan Africa.

When compared to the conventional UNDP index, the IHDI provides systematically lower levels of human development for the developing countries. As a result the gap between rich and poor countries is highlighted and a much less optimistic view than the conventional UNHDI results, justifying the concern for international differences expressed in Human Development Reports. These sobering new findings highlight the need to increase levels of human development in developing countries while suggesting some weaknesses that required to be addressed, in particular, health improvements to enhance life expectancy and further stress on secondary and tertiary education.

\section{Acknowledgements}

Earlier versions of this paper were presented at the Copenhagen Institute of Economics and the European University Institute, Florence. I am indebted to Giovanni Federico, Christian Morrisson, Jim Riley, Joan Rosés, Isabel Sanz-Villarroya and Giovanni Vecchi for their suggestions. I am most grateful to Alexander Apostolides, Pablo Astorga, Facundo Alvaredo, Luis Bértola, Peter Boomgaard, Victor Bulmer-Thomas, Joaquim da Costa Leite, Mark Harrison, Salomón Kalmanovitz, Bruno Monasterio, Christian Morrisson, Fabrice Murtin, Les Oxley, Sevket Pamuk, David Reher, Alvaro Ferreira da Silva, Jan-Pieter Smits, Socrates Petmetzas and Marianne Ward for kindly sharing their data. Financial support from the Spanish Ministry of Science and Innovation (Research Project 'Consolidating Economics', Consolider-Ingenio 2010 Programme), the HI-POD Project, Seventh Research Framework Programme Contract no. 225342, and Fundación Rafael del Pino's Research Project on 'Economic Freedom in History' is highly appreciated. The usual disclaimer applies.

\section{Notes}

1. Welfare economics is meant here in a broad sense and not restricted to conventional 'welfare economics'. 
2. Cf. Adelman and Morris (1967), Beckerman (1966), Beckerman and Bacon (1966), Ehrlich (1969), Heston (1973), Hicks and Streeten (1979), Larson and Wilford (1979), Morris (1979), Streeten et al. (1981), McGranahan et al. (1985) and Ram (1982).

3. The human development index has been received favourably, though uncritically, among economic historians who perceive it as a 'retrospective index of welfare' (Costa and Steckel, 1997, pp. 73-74) and have been adapted it imaginatively to the available evidence (Steckel and Floud, 1997a; Astorga and Fitzgerald, 1998; Astorga et al., 2005).

4. For life expectancy at birth the maximum and the minimum values are established at 85 and 25 years, respectively. For education, the maximum and minimum are 100 and 0 . The education index combines adult literacy and gross enrolment (primary, secondary and tertiary), with two-thirds and one-third weights, respectively. In the case of per capita GDP, a logarithmic transformation is imposed to allow for its assumed diminishing returns in terms of human development, and the maximum and minimum values are the logarithms of 40,000 and 100 dollars, respectively.

5. Mazumdar (1999) has, nonetheless, widened the PIQL index to include other social dimensions in an attempt to measure the quality of life.

6. The nature of its sponsor, its world coverage and its annual availability suggest, however, that the HDI may last longer than previous attempts at assessing wellbeing.

7. Thus, the HDI adds up social indicators for various domains of individual wellbeing but does not derive an aggregate of individual indices (Fleurbaey, 2009, p. 1055). Hicks (1997), Grimm et al. (2008), and Bértola et al. (2008) provide alternative human development measures allowing for income distribution.

8. Unfortunately, most of these shortcomings tend to be unavoidable in historical studies.

9. That is, the age coverage differs widely (figures for population above 7, 10 or 15 years old are simultaneously used) and often the literate population includes those who can read but cannot write. Similarly, enrolment figures are incomplete as the non-public sector is usually neglected. Moreover, comparability between very different writing systems (Chinese ideograms versus western alphabet, for example) is fraught with difficulties (Lind, 2004).

10. It can be argued, however, that life tables' projections can be superior to imperfectly collected data on life expectancy.

11. An additional worry derives from the fact that the HDI combines stock and flow variables. It has been suggested that if an annual index is required as a measure of progress, it should be computed on annual basis with flow data and preferably taking into account yearly changes in per capita income, in infant mortality and in school enrolment (Aturupane et al., 1994, p. 246).

12. 'If they are mutually orthogonal, then each measures an aspect of development unrelated to that measured by any other. At the other extreme, if they perfectly correlate with each other, then all indicators measure the same aspect' (Srinivasan, 1994, p. 240).

13. PCA is a statistical technique for transforming a large set of variables into a smaller set of uncorrelated variables that accounts for most of the variation in the original variables. The principal components are linear combinations of the original variables with characteristic vectors of the correlation matrix of original variables as weights. 


\section{IMPROVING HUMAN DEVELOPMENT}

The first principal component captures the largest proportion of the variation in the original set of variables.

14. See Ram (1982) for a pioneering use of PCA to computing the physical index of quality of life. Also, see Ogwang (1994), Ogwang and Abdou (2003) and Lai (2000).

15. Cf. Chakravarty (2003). This conclusion contradicts Ogwang (1994) who used PCA to identify a single variable (life expectancy) which best represents the three constituent elements of the HDI and, hence, to eliminate the problem of arbitrary choice of weights.

16. Kelley (1991, p. 319) argued that the 'production-transformation between income per capita and other human development indicators may be nonlinear, and thus might justify unequal or even variable weights by income level'.

17. This choice has been justified as human development is a concept that goes beyond the utilitarian calculus deliberately (Desai, 1991, p. 354).

18. Preston (1975, pp. 236-237) stressed that the relationship between life expectancy and GDP per head shifted upwards over the 20th century, and countries attained higher life expectancy at lower income levels as time went by.

19. The variances of the principal components are equal to the associated characteristic roots. The proportion of the variation ascribed to a particular principal component is obtained by dividing the associated characteristic root by the sum of all the characteristic roots.

20. Cf. UNDP (1993) and Ogwang (1994).

21. The striking trade off between per capita income and longevity arises 'from the fact that the marginal effect on the HDI of longer life is a constant', while at the same time, 'the marginal effect of extra income falls very sharply as income increases' (Ravallion, 1997, p. 633). Such a result is supported by the results obtained by Dowrick et al. (2003, p. 525) who argue that 'life expectancy in many parts of the world could be extended at a surprisingly low cost'. However, they criticize the UNHDI for implicitly valuing 'life expectancy above its opportunity cost'.

22. For example, in the case of longevity, 'a further increase must be regarded as a greater achievement than an equal increase at lower levels of longevity,... the achievement must increase at a faster rate than the longevity' (Kakwani, 1993, p. 313).

23. The same reasoning is reproduced in Dasgupta and Weale (1992, p. 125) who, nonetheless, make an exception in the case of literacy: 'It is not immediately apparent why it should be a lot less or a lot more difficult to increase the literacy rate when people are more literate'.

24. The fact that the human development index aims at reflecting human needs does not necessarily imply that differences across countries should be forced to narrow down. On the contrary, the reader will notice the stress HDR place on such differences in sharp contrast with the evidence provided by the UNHDI.

25. Altering goalposts is not new. For example, Dasgupta (1990) and Kakwani (1993) used 80 years as the maximum goalpost for life expectancy at birth in present time developing countries.

26. Truncating the lower part of the distribution by assuming a 'floor' of 25 years of life expectancy, which is not far from the actual value in the poorest developing countries, both in the present and in the past, has the advantage of allowing one to consider countries for which no data exist. The alternative option would be to 


\section{ESCOSURA}

reduce the country sample. Moreover, accepting a minimum value, $M_{0}$, of 24 years precludes a zero value for the transformed life expectancy.

27. The assumption of $1 \%$ as the lowest historical value for literacy and enrolment seems more reasonable than accepting zero as in the UNHDI, although a historical maximum of $99 \%$ is also accepted in the UNHDI. The consequence of assuming a historical lower bound of $1 \%$ is preventing zero values for the transformed variables.

28. Empirical evidence strongly rejects the conventional results obtained through the trading exchange rate converter (Summers and Heston, 1991; van Ark, 1993).

29. See the discussion in Prados de la Escosura (2000). Ward and Devereux (2003) have accepted the challenge to build direct PPP estimates from the expenditure side for 12 western economies at five benchmarks (1872, 1884, 1905, 1930 and 1950).

30. Maddison (2009) and Conference Board (2010) estimates era provide the best and most recent examples.

31. A significant strand of the literature defends the view defends that the best estimates of growth rates are those obtained from national accounts (Bhagwati and Hansen, 1973; Isenman, 1980; Kravis and Lipsey, 1991; Maddison, 1991, 1995) on the grounds that 'using domestic prices to measure growth rates is more reliable, because those prices characterize the trade offs faced by the decision making agents' (Nuxoll, 1994).

32. This lower bound for per capita income which, no doubt, truncates the data set at the bottom, allows me to consider countries in earlier periods for which no data exist and that, otherwise, would reduce the country sample considered here.

33. Thus, I have spliced the four sample estimates into a single one in which the levels for each world region $i$ in the larger country sample $\left(X_{i 1990}\right)$ are accepted and earlier benchmark estimates $\left(X_{i t}\right.$, for $\left.t=1870,1913,1950\right)$ are successively re-scaled up to match the new benchmark level $X^{\prime}$ for the year $(o)$ in which each pair of benchmark estimates overlap, $X_{i t}^{\prime}=\left(X_{i o}^{\prime} / X_{i o}\right) * X_{i t}$.

34. The Organization for Economic Cooperation and Development (OECD), created in Paris on 14th December 1960, included 20 countries from Western Europe and the Western Offshoots (Australia, Canada, New Zealand and the USA). Today it includes 32 countries. In this paper OECD refers to its pre-1995 membership: Australia, Austria, Belgium, Canada, Denmark, Finland, France, Germany, Greece, Iceland - only since 1990, Ireland, Italy, Japan, Luxembourg, Netherlands, New Zealand, Norway, Portugal, Spain, Sweden, Switzerland, Turkey, the UK and the USA. Luxembourg has been excluded due to lack of data. Turkey has also been excluded in order to have a more homogeneous group in terms of economic and social development and was allocated to the Asia group. New members since 1995: Czech Republic, Hungary and Slovakia, are included in Eastern Europe; South Korea, in Asia; and Mexico, in Latin America.

35. Nonetheless, these results support the view that human development in today's less developed countries compare favourably with that of developed countries in the late 19th century (Crafts, 2002).

\section{References}

Adelman, I. and Morris, C.T. (1967) Society, Politics and Economic Development. Baltimore, MD: Johns Hopkins University Press.

Altug, S., Filiztekin, A. and Pamuk, S. (2008) Sources of long-term growth for Turkey, 1880-2005. European Review of Economic History 12(3): 393-430. 


\section{IMPROVING HUMAN DEVELOPMENT}

Alvaredo, F. and Atkinson, A.B. (2010) Colonial rule, apartheid and natural resources: top incomes in South Africa 1903-2005. Mimeo, Department of Economics, University of Oxford.

van Ark, B. (1993) The ICOP approach. Its implications and applicability. In A. Szirmai, B. van Ark and D. Pilat (eds), Explaining Economic Growth (pp. 375-398). Amsterdam: North-Holland.

Arriaga, E.E. (1968) New Life Tables for Latin American Populations in the Nineteenth and Twentieth Centuries. Population Monographs Series No. 3. Berkeley, CA: Institute of International Studies, University of California.

Astorga, P. and Fitzgerald, V. (1998) Statistical appendix. In R. Thorp (ed.), Progress, Poverty and Exclusion: An Economic History of Latin America in the 20th Century (pp. 307-365). Washington, DC: Inter-American Development Bank.

Astorga, P., Bergés, A.R. and FitzGerald, E.V.K. (2003) The Oxford Latin American Economic History Database (OxLAD). Oxford: Latin American Centre, Oxford University. Available at http://oxlad.qeh.ox.ac.uk/ (last accessed 19 April 2010).

Astorga, P., Berges, A.R. and Fitzgerald, E.V.K. (2005) The standard of living in Latin America during the twentieth century. Economic History Review 63(4): 765-796.

Aturupane, H., Glewwe P. and Isenman P. (1994) Poverty, human development, and growth: an emerging consensus? American Economic Review, Papers and Proceedings 84(2): 244-249.

Ayeni, O. (1976) Retrospective estimates of mortality from the Nigerian medical censuses of 1930-1932: a research note. Nigerian Journal of Economic and Social Studies 18: 461-469.

Bakker, G.P., den Huitker, T.A. and van Bochove, C.A. (1990) The Dutch economy 1921-1938: revised macroeconomic data for the interwar period. Review of Income and Wealth 36: 187-206.

Banks, A.S. (2010) Cross-National Time-Series Data Archive, http://www. databanksinternational.com/ (last accessed 3 May 2010).

Baptista, A. (1997) Bases Cuantitativas de la Economía Venezolana, 1830-1995. Caracas: Fundación Polar.

Barro, R. and Lee, J.W. (2002) International data on educational attainment: updates and implications. Working Paper 42, Harvard University Center for International Development CID. Accompanying dataset available at http://www.ksg.harvard.edu/CID (last accessed 15 April 2009).

Batista, D., Martins, C., Pinheiro, M. and Reis, J. (1997) New Estimates of Portugal's GDP 1910-1958. Lisbon: Banco de Portugal.

Beckerman, W. (1966) International Comparisons of Real Incomes. Paris: OECD Development Centre.

Beckerman, W. (1993) Is economic growth still desirable?. In A. Szirmai, B. van Ark and D. Pilat (eds), Explaining Economic Growth. Essays in Honour of Angus Maddison (pp. 77-100). Amsterdam: North-Holland.

Beckerman, W. and Bacon, R. (1966) International comparisons of income levels: a suggested new measure. Economic Journal 76(303): 519-536.

Benavot, A. and Riddle P. (1988) The expansion of primary education, 1870-1940: trends and issues. Sociology of Education 61(3): 191-210.

Bértola, L. (1998) El PBI de Uruguay, 1870-1936 y Otras Estimaciones. Montevideo: Universidad de la República.

Bértola, L., M. Camou, S. Maubrigades, and N. Melgar (2008), "Human Development and Inequality in the $20^{\text {th }}$ Century: the Mercosur Countries in a Comparative Perspective", Universidad Carlos III Working Papers in Economic History 08-06.

Bhagwati, J.N. and Hansen, B. (1973) Should growth rates be evaluated at international prices? In J.N. Bhagwati and R.S. Eckaus (eds), Development and Planning: Essays in Honour of Paul Rosenstein-Rodan (pp. 53-68). Cambridge, MA: MIT Press. 


\section{ESCOSURA}

Booysen, F. (2002) An overview and evaluation of composite indices of development. Social Indicators Research 59(2): 115-151.

Bourbeau, R., Légaré, J. and Émond, V. (1997) New Birth Cohort Life Tables for Canada and Quebec,1801-1991. Research Paper No. 3, Statistics Canada, Demographic Division. Available at www.statcan.ca (last accessed 8 May 2008).

Bourguignon, F. and Morrisson, C. (2002) Inequality among world citizens. American Economic Review 92(4): 727-744.

Braun, J., Braun, M., Briones, I. and Díaz, J. (2000) Economía chilena, 1810-1995. Estadísticas históricas. Pontificia Universidad Católica de Chile, Instituto de Economía, Documento de Trabajo no. 187.

Brundenius, C. and Zimbalist, A. (1989) The Cuban Economy: Measurement and Analysis of Socialist Performance. Baltimore, MD: Johns Hopkins University Press.

Bureau of Economic Analysis (2010) GDP by Industry, 1910 to 2009. Available at http://www.bea.gov/industry/iotables/prod/table_list.cfm?anon=56082 (last accessed 5 May 2010).

Buyst, E. (1997) New GNP estimates for the Belgian economy during the interwar period. Review of Income and Wealth 43: 357-375.

Caldwell, J., Bracher, M., Santow, G. and Caldwell P. (1986) Population trends in China - a perspective provided by the 1982 census. In C. Li (ed.), A Census of One Billion People (pp. 352-391). Hong Kong: Republic of China Population Census Office.

CEPAL (2009) América Latina y el Caribe. Series históricas de estadísticas económicas 1950-2008. Cuadernos Estadísticos 37, Comisión Económica para América Latina y el Caribe. Available at http://www.eclac.cl/deype/cuaderno37/index.htm (last accessed 5 February 2010).

Cha, M.S. and Kim, N.N. (2006) Korea's first industrial revolution, 1911-40. Naksungdae Institute of Economic Research (NIER) Working Papers Series 2006-3. Available at http://www.naksung.re.kr/papers/wp2006-3.pdf (last accessed 17 March 2010).

Cha, M.S. and Wu, T.M. (2002) Colonial transition to modern economic growth in Korea and Taiwan. Mimeo, Yeungnam University and National Taiwan University.

Chakravarty, S.R. (2003) A generalized human development index. Review of Development Economics 7(1): 99-114.

Coatsworth, J.H. (1989) The decline of the Mexican economy, 1800-1860. In R. Liehr (ed.), América Latina en la época de Simón Bolívar. La formación de las economías nacionales y los intereses económicos europeos 1800-1850 (pp. 27-53). Berlin: Colloquium.

Cohen, D. and Soto, M. (2007) Growth and human capital: good data, good results. Journal of Economic Growth 12(1): 51-76.

Conference Board (2010) Total Economy Database, January 2010. Available at http://www.conference-board.org/economics/database.cfm (last accessed 15 April 2010).

Conte, L., della, Torre G. and Vasta, M. (2007) The human development index in historical perspective: Italy from political unification to the present day. Quaderni Università degli Studi di Siena, Dipartimento di Economia Politica No. 491.

Cortés Conde, R. (1997) La economía argentina en el largo plazo. Buenos Aires: Editorial Sudamericana/ Universidad de San Andrés.

Costa, D.L. and Steckel, R.H. (1997) Long-term trends in health, welfare, and economic growth in the United States. In R.H. Steckel and R. Floud (eds), Health and Welfare during Industrialization (pp. 47-89). Chicago, IL: University of Chicago Press.

Crafts, N. (1997) The human development index and changes in standards of living: some historical comparisons. European Review of Economic History 1(3): 299-322.

Crafts, N. (2002) The human development index, 1870-1999: some revised estimates. European Review of Economic History 6(3): 395-405. 


\section{IMPROVING HUMAN DEVELOPMENT}

Cutler, D. and Miller, G. (2005) The role of public health improvements in health advance: the twentieth century United States. Demography 42(1): 1-22.

Dasgupta, P. (1990) Well-being and the extent of its realization in poor countries. Economic Journal 100(400): 1-32.

Dasgupta, P. (1993) An Inquiry into Well-Being and Destitution. Oxford: Clarendon Press.

Dasgupta, P. and Weale, M. (1992) On measuring the quality of life. World Development 20(1): 119-131.

Della Paolera, G., Taylor, A.M. and Bozolli, C.G. (2003) Historical statistics. In G. Della Paolera and A.M. Taylor (eds), A New Economic History of Argentina (pp. 376-385). New York: Cambridge University Press (with CD-ROM).

Deprez, P. (1979) The low countries. In W.R. Lee (ed.), European Demography and Economic Growth (pp. 236-283). London: Croom Helm.

Desai, M. (1991) Human development: concept and measurement. European Economic Review 35: 350-357.

Díaz, J., Lüders, R. and Wagner, G. (2007) Economía Chilena 1810-2000. Producto total y sectorial. Una nueva mirada. Pontificia Universidad Católica de Chile, Documento de trabajo 315.

Domínguez, R. and Guijarro, M. (2000) Evolución de las disparidades espaciales del bienestar en España, 1860-1930: El Índice Físico de Calidad de Vida. Revista de Historia Económica 18(1): 109-137.

Dopico, F. and Reher, D.S. (1998) El declive de la mortalidad en España, 1860-1930. Asociación de Demografía Histórica, Monografía No. 1.

Dowrick, S., Dunlop, Y. and Quiggin, J. (2003) Social indicators and comparisons of living standards. Journal of Development Economics 70: 501-529.

Easterlin, R. (1999) How beneficent is the market? A look at the modern history of mortality. European Review of Economic History 3(3): 257-294.

Easterly, W. (1999) Life after growth. Journal of Economic Growth 4(3): 239-276. Underlying data available at http://www.worldbank.org/html/prdmg/grthweb/growtht.htm (last accessed 13 March 2009).

Eckstein, A. (1955) National income and capital formation in Hungary, 1900-1950. Income and Wealth, 5: 150-223.

Ehrlich, E. (1969) Dynamic international comparisons of national incomes expressed in terms of physical indicators. Osteuropa Wirtschaft 14: 1-25.

Eisner, G. (1961) Jamaica, 1830-1930: A Study in Economic Growth. Manchester: Manchester University Press.

Engerman, S.L. (1997) The standard of living debate in international perspective: measures and indicators. In R.H. Steckel and R. Floud (eds), Health and Welfare during Industrialization (pp. 17-45). Chicago, IL: University of Chicago Press.

Fargues, P. (1986) Un siècle de transition démographique en Afrique méditerranéenne 1885-1985. Population 41(2): 205-232.

Federico, G. and Toniolo, G. (1991) Italy. In R. Sylla and G. Toniolo (eds), Patterns of European Industrialization. The Nineteenth Century (pp. 197-217). London: Routledge.

Feinstein, C.H. (2005) An Economic History of South Africa. Conquest, Discrimination and Development. Cambridge: Cambridge University Press.

Fenoaltea, S. (2005) The growth of the Italian economy, 1861-1913: preliminary secondgeneration estimates. European Review of Economic History 9: 273-312.

Fleurbaey, M. (2009) Beyond GDP: the quest for a measure of social welfare. Journal of Economic Literature 47(4): 1029-1075.

Flora, P. (1973) Historical processes of social mobilization: urbanization and literacy, 1850-1965. In S.N. Eisenstadt and S. Rokkan (eds), Building States and Nations: Models and Data Resources (pp. 213-258). London: Sage.

Flora, P. (1983) State, Economy, and Society in Western Europe 1815-1975. A Data Handbook in Two Volumes. Frankfurt: Campus Verlag. 


\section{ESCOSURA}

Floud, R. and Harris, B. (1997) Health, height, and welfare: Britain, 1700-1980. In R.H. Steckel and R. Floud (eds), Health and Welfare during Industrialization (pp. 91-126). Chicago, IL: University of Chicago Press.

Glass, D.V. and Grebenik, E. (1967) World population, 1800-1950. In H.J. Habakkuk and M. Postan (eds), Cambridge Economic History of Europe. Vol. VI: The Industrial Revolutions and After: Incomes, Population, and Technological Change (I) (pp. 56-138). Cambridge: Cambridge University Press.

Goerlich Gisbert, F. and Pinilla Pallejá, R. (2005) Esperanza de vida y potencial de vida a lo largo del siglo XX en España. Revista de Demografía Histórica 23(2): 79-109.

Goldsmith, R.W. (1961) The economic growth of Tsarist Russia: 1860-1913. Economic Development and Cultural Change 9: 441-475.

Goldsmith, R.W. (1986) Desenvolvimento Financeiro Sob Um Século de Inflaçao. Rio de Janeiro: Harper \& Row do Brasil.

Good, D.F. (1994) The economic lag of Central and Eastern Europe: income estimates for the Habsburg successor states, 1870-1910. Journal of Economic History 54(4): 869-891.

Gormely, P.J. (1995) The human development index in 1994: impact of income on country rank. Journal of Economic and Social Measurement 21: 253-267.

Greasley, D. and Oxley, L. (2000a) Measuring New Zealand's GDP 1865-1933. Review of Income and Wealth 46, 351-368.

Greasley, D. and Oxley, L. (2000b) Outside the club: New Zealand's economic growth 1870-1993. International Review of Applied Economics 14: 173-192.

GRECO (Grupo de Estudios de Crecimiento Económico) (2002) El Crecimiento Económico Colombiano en el Siglo XX. Bogotá: Banco de la República - Fondo de Cultura Económica.

Gregory, P. (1982) Russian National Income. Cambridge: Cambridge University Press.

Grimm, M., Harttgen, K., Klasen, S. and Misselhorn, M. (2008) A human development index by income groups. World Development 36(12): 2527-2546.

Grytten, O.H. (2004) The gross domestic product for Norway 1830-2003. In Ø. Eitrheim, J.T. Klovland and J.F. Qvigstad (eds), Historical Monetary Statistics for Norway 1819-2003 (pp. 241-288). Oslo: Norges Bank, Norges Bank Occasional Papers no. 35 .

Haines, M. (1994) Estimated life tables for the United States, 1850-1900. National Bureau of Economic Research Working Paper Series 15 on Historical Factors in Long Run Growth.

Hanley, S.B. (1990) The relationship between education and economic growth. In G. Tortella (ed.), Education and Economic Development since the Industrial Revolution (pp. 69-87). Valencia: Generalitat Valenciana.

Hansen, S.A. (1974) Økonomisk vakst i Danmark. Copenhagen: Akademisk Forlag.

Hayami, Y. and Ruttan, V.W. (1985) Agricultural Development: An International Perspective. Baltimore, MD: Johns Hopkins University Press.

Helczmanovski, H. (1979) Austria-Hungary. In W. R. Lee (ed.), European Demography and Economic Growth (pp. 27-78). London: Croom Helm.

Heston, A. (1973) A comparison of some short-cut methods of estimating real product per capita. Review of Income and Wealth 19(1): 79-104.

Heston, A. (1994) A brief review of some problems in using national accounts data in level of output comparisons and growth studies. Journal of Development Economics 44: 29-52.

Hicks, D.A. (1997) The inequality-adjusted human development index: constructive proposal. World Development 28(8): 1283-1298.

Hicks, N. and Streeten, P. (1979) Indicators of development: the search for a basic needs yardstick. World Development 7: 567-580. 


\section{IMPROVING HUMAN DEVELOPMENT}

Hjerppe, R. (1996) Finland's Historical National Accounts 1860-1994: Calculation Methods and Statistical Tables. Jyväskylä: J.Y.H.L.

Hoffmann, W.G., Grumbach, F. and Hesse, H. (1965) Das Wachstum der Deutschen Wirtschaft seit der Mitte des 19.Jahrhunderts. Berlin: Springer.

Honda, G. (1997) Differential structure, differential health: industrialization in Japan, 1868-1940. In R.H. Steckel and R. Floud (eds), Health and Welfare during Industrialization (pp. 251-284). Chicago, IL: University of Chicago Press.

Hopkins, M. (1991) Human development revisited: a new UNDP report. World Development 19(10): 1469-1473.

Horlings, E. (1997) The contribution of the service sector to gross domestic product in Belgium, 1835-1990. Mimeo, Universiteit Utrecht, Utrecht.

INEGI (1995) Estadísticas históricas de México. México DF: INEGI.

International Monetary Fund (IMF) (2010) International Financial Statistics. Washington, DC: IMF.

Isenman, P. (1980) Inter-country comparison of 'real' (PPP) incomes: revised estimates and unresolved questions. World Development 8(1): 61-72.

Jannetta, A.B. and Preston, S.H. (1991) Two centuries of mortality change in central Japan: the evidence from a temple death register. Population Studies 45(3): 417-436.

Jayachandran, S., Lleras-Muney, A. and Smith, K.V. (2010) Modern medicine and the twentieth century decline in mortality: evidence on the impact of sulfa drugs. American Economic Journal: Applied Economics 2(2): 118-146.

Johansson, S.R. and Mosk, C. (1987) Exposure, resistance and life expectancy: disease and death during the economic development of Japan, 1900-1960. Population Studies 41(2): 207-235.

Kakwani, N. (1993) Performance in living standards. An international comparison. Journal of Development Economics 41: 307-336.

Kalmanovitz Krauter, S. and López Rivera, E. (2009) Las Cuentas Nacionales de Colombia en el Siglo XIX. Bogotá: Universidad de Bogotá Jorge Tadeo Lozano.

Kannisto, V., Nieminen, M. and Turpeinen, O. (1999) Finnish life tables since 1751. Demographic Research 1, 1. Available at www.demographic-research.org/Volumes/ Vol1/1 (last accessed in 27 February 2009).

Kelley, A.C. (1991) The human development index: 'handle with care'. Population and Development Review 17: 315-324.

Kendrick, J.W. (1961) Productivity Trends in the United States. Princeton, NJ: National Bureau of Economic Research.

Keyfitz, N. and Fleiger, W. (1968) World Population: An Analysis of Vital Data. Chicago, IL: University of Chicago Press.

Kimura, M. (1990) Diffusion of primary education in Korea. In G. Tortella (ed.), Education and Economic Development since the Industrial Revolution (pp. 337-353). Valencia: Generalitat Valenciana.

Kostelenos, G. and Associates (2007) Gross Domestic Product, 1830-1939 (in Greek). Athens: Centre of Planning and Economic Research (KEPE).

Krantz, O. and Schön, L. (2007) Swedish Historical National Accounts 1800-2000. Aggregate Output Series. Lund: Lund University.

Kravis, I.B. and Lipsey, R.E. (1991) The international comparison program: current status and problems. In P.E. Hooper and J.D. Richardson (eds), International Economic Transactions: Issues in Measurement and Empirical Research (pp. 437-464). Studies in Income and Wealth 55. Chicago, IL: NBER and University of Chicago Press.

Lai, D. (2000) Temporal analysis of human development indicators: principal component approach. Social Indicators Research 51(3): 331-366.

Lains, P. (2006) Growth in a protected environment: Portugal, 1850-1950. Research in Economic History 24: 121-163. 


\section{ESCOSURA}

Langford, C., and Storey, P. (1993) Sex differentials in mortality early in the twentieth century: Sri Lanka and India compared. Population and Development Review 19(2): 263-282.

Larson, D.A. and Wilford, W.T. (1979) The physical quality of life index: a useful social indicator? World Development 7: 581-584.

Lavely, W. and Wong, R.B. (1998) Revising the Malthusian narrative: the comparative study of population dynamics in late imperial China. Journal of Asian Studies 57(3): 714-748.

Leite, J. da Costa (2005) Populaçao e crescimento económico. In P. Lains and A. Ferreira da Silva (eds.), História Económica de Portugal 1700-2000 (Vol. II, O Século XIX, pp. 43-81). Lisboa: Impresa de Ciências Sociais.

Lewis, W.A. (1955) The Theory of Economic Growth. London: George Allen and Unwin.

Lindert, P.H. (2004) Growing Public. Social Spending and Economic Growth since the Eighteenth Century ( 2 vols). Cambridge: Cambridge University Press.

Loudon, I. (2000) Maternal mortality in the past and its relevance to developing countries today. American Journal of Clinical Nutrition 72, 1 (supplement): 241S-246S.

Maddison, A. (1991) Dynamic Forces in Capitalist Development. A Long-run Comparative View. Oxford: Oxford University Press.

Maddison, A. (1995) Monitoring the World Economy, 1820-1992. Paris: OECD Development Centre.

Maddison, A. (2006) The World Economy. Paris: OECD Development Centre.

Maddison, A. (2009) Statistics on World Population, GDP and Per Capita GDP, 1-2006 AD. Last update: March 2009, horizontal file. Available at http://www.ggdc.net/maddison/ (last accessed 27 July 2009).

Markevich, A. and Harrison, M. (2009) Russia's real national income: the Great War, Civil War, and Recovery, 1913 to 1928. Warwick Economic Research Papers 911.

Markussen, I. (1990) The development of writing ability in Nordic countries in the eighteenth and nineteenth centuries. Scandinavian Journal of History 15: 37-63.

Mazumdar, K. (1999) Measuring the well-beings of the developing countries: achievement and improvement indices. Social Indicators Research 47(1): 1-60.

Mazur, D.P. (1969) Expectancy of life at birth in 36 nationalities of the Soviet Union: 1958-60. Population Studies 23(2): 225-246.

McAlpin, M.B. (1983) Famines, epidemics, and population growth: the case of India. Journal of Interdisciplinary History 14(2): 352-366.

McGillivray, M. (1991) The human development index: yet another redundant composite development indicator? World Development 19(10): 1461-1468.

McGranahan, D.V., Pizarro, P. and Richard, C. (1985) Measurement and Analysis of Socio-Economic Development. Geneva: United Nations Research Institute for Social Development (UNRISD).

McKeown, T., Record, R.G. and Turner, R.D. (1975) An interpretation of the decline of mortality in England and Wales during the twentieth century. Population Studies 29(3): 391-422.

McKinlay, J.B. and McKinlay, S.M. (1977) The questionable contribution of medical measure to the decline of mortality in the United States in the twentieth century. Milbank Memorial Fund Quarterly. Health and Society 55(3): 405-428.

Milanovic, B., Lindert, P.H. and Williamson, J.G. (2007) Measuring ancient inequality. Working Paper 13550, National Bureau of Economic Research. Available at http://www.nber.org/papers/w13550 (last accessed 29 June 2009).

Ministerio de Salud Pública (2001) Tablas de Mortalidad del Uruguay por sexo y edad 1908-1999. Montevideo: Ministerio de Salud Pública, Dirección General de la Salud, Departamento de Estadística.

Mironov, B.N. (1991) The development of literacy in Russia and the USSR from the tenth to the twentieth centuries. History of Education Quarterly 31(2): 229-252. 


\section{IMPROVING HUMAN DEVELOPMENT}

Mironov, B.N. (1993) Educación y desarrollo económico en Rusia, siglos XIX y XX. In C.E. Núñez and G. Tortella (eds), La maldición divina. Ignorancia y atraso en perspectiva histórica (pp. 271-306). Madrid: Alianza.

Mitchell, B.R. (1988) British Historical Statistics. Cambridge: Cambridge University Press.

Mitchell, B.R. (2003a) International Historical Statistics: Africa, Asia, and Oceania 1750-2000. New York: Palgrave Macmillan.

Mitchell, B.R. (2003b) International Historical Statistics: The Americas, 1750-2000, 5th edn. New York: Palgrave Macmillan.

Mitchell, B.R. (2003c) International Historical Statistics: Europe 1750-2000. New York: Palgrave Macmillan.

Morris, M.D. (1979) Measuring the Condition of the World's Poor: The Physical Quality of Life Index. New York: Pergamon.

Morrisson, C. and Murtin, F. (2007) Education inequalities and the Kuznets curves: a global perspective since 1870. Paris School of Economics Working Papers 20072012.

Morrisson, C. and Murtin, F. (2009) The century of education. Journal of Human Capital 3(1): 1-42 (and data appendix)

Myllantaus, T. (1990) Education in the making of modern Finland. In G. Tortella (ed.), Education and Economic Development since the Industrial Revolution (pp. 153-171). Valencia: Generalitat Valenciana.

Newland, C. (1991) La educación elemental en Hispanoamérica: desde la independencia hasta la centralización de los sistemas educativos nacionales. Hispanic American Historical Review 71(2): 335-364.

Nicolau, R. (2005) Población, salud y actividad. In A. Carreras and X. Tafunell (eds), Estadísticas Históricas de España. Siglos XIX-XX, 3 vols (Vol. II, pp. 77-154). Madrid: Fundación BBVA.

Nilsson, A. (1999) What do literacy rates in the 19th century really signify? New light on an old problem from unique Swedish data. Paedagogica Historica 35(2): 275-296.

Noorbakhsh, F. (1998) A modified human development index. World Development 26(3): 517-528.

Notkola, V., Timaeus, I.M. and Siiskonen, H. (2000) Mortality transition in the Ovamboland region of Namibia, 1930-1990. Population Studies 54(2): 153-167.

Nunes, A.B. (1993) Education and economic growth in Portugal: a simple regression approach. Estudos de Economia 13(2): 181-205.

Núñez, C.E. (2005) Educación. In A. Carreras and X. Tafunell (eds), Estadísticas Históricas de España, Siglos XIX y XX. Bilbao: Fundación BBBV.

Núñez, J. (2005) Signed with an X: methodology and data sources for analyzing the evolution of literacy in Latin America and the Caribbean, 1900-1950. Latin American Research Review 40(2): 117-135.

Nuxoll, D.A. (1994) Differences in relative prices and international differences in growth rates. American Economic Review 84: 1423-1436.

Ogwang, T. (1994) The choice of principal components for computing the human development index. World Development 19: 1461-1468.

Ogwang, T. and Abdou, A. (2003) The choice of principal variables for computing some measures of human well-being. Social Indicators Research 64: 139-152.

Ouane, A. and Amon-Tanoh, Y. (1990) Literacy in French-speaking Africa: a situational analysis. African Studies Review 33(3): 21-38.

Pamuk, S. (2006) Estimating economic growth in the Middle East since 1820. Journal of Economic History 66(3): 809-828.

Pamuk, S. (2007) Economic change in twentieth century Turkey: is the glass more than half full? American University of Paris Working Paper 41. 


\section{ESCOSURA}

Prados de la Escosura, L. (2000) International comparisons of real product, 1820-1990: an alternative data set. Explorations in Economic History 37(1): 1-41.

Prados de la Escosura, L. (2003) El progreso económico de España. 1850-2000. Madrid: Fundación BBVA, updated.

Pressat, R. (1985) Historical perspectives on the population of the Soviet Union. Population and Development Review 11(2): 315-334.

Preston, S.H. (1975) The changing relationship between mortality and level of economic development. Population Studies 29(2): 231-248.

Ram, R. (1982) Composite indices of physical quality of life, basic needs fulfilment, and income. A principal component representation. Journal of Development Economics 11: 227-247.

Ravallion, M. (1997) Good and bad growth: the human development reports. World Development 25(5): 631-638.

Recchini de Lattes, Z. and Lattes, A.E. (eds) (1975) La población de Argentina. Buenos Aires: Instituto Nacional de Estadística y Censos.

Reis, J. (1993) El analfabetismo en Portugal en el siglo XIX: una interpretación. In C.E. Núñez and G. Tortella (eds), La maldición divina. Ignorancia y atraso en perspectiva histórica (pp. 237-269). Madrid: Alianza.

Riley, J.C. (2005a) Estimates of regional and global life expectancy, 1800-2001. Population and Development Review 31(3): 537-543.

Riley, J.C. (2005b) The timing and pace of health transitions around the world. Population and Development Review 31(4): 741-764.

Riley, J.C. (2005c) Bibliography of works providing estimates of life expectancy at birth and estimates of the beginning period of health transitions in countries with a population in 2000 of at least 400,000. Available at www.lifetable.de/RileyBib.htm (last accessed 15 February 2010).

Ritschl, A. and Spoerer, M. (1997) Das bruttosozialprodukt in Deutschland nach den amtlichen Volseinkommes- und Sozialproduktsstatistiken 1901-1995. Jahrbuch für Wirtschaftsgeschichte 2: 27-54.

Sagar, A.D. and Najam, A. (1998) The human development index: a critical review. Ecological Economics 25: 249-264.

Sandberg, L.G. and Steckel, R.H. (1997) Was industrialization hazardous to your health? Not in Sweden. In R.H. Steckel and R. Floud (eds), Health and Welfare during Industrialization (pp. 127-159). Chicago, IL: University of Chicago Press.

Santamaría, A. (2005) Las cuentas nacionales de Cuba, 1690-2005. Mimeo, Centro de Estudios Históricos, Centro Superior de Investigaciones Científicas.

Sarkar, N.K. (1951) A note on abridged life tables for Ceylon, 1900-1947. Population Studies 4(4): 439-443.

Schulze, M.S. (2000) Patterns of growth and stagnation in the late nineteenth century Habsburg economy, European Review of Economic History 4(3): 311340.

Sen, A. (1997) Human capital and human capability. World Development 25(12): 1959-1961.

Shorter, F.C. and Macura, M. (1982) Trends in Fertility and Mortality in Turkey 1935-1975. Washington, DC: National Academy Press.

Siampos, G.S. (1970) The population of Cambodia, 1945-1980. Milbank Memorial Fund Quarterly 48: 317-360.

Simkins, C. and van Heyningen, E. (1989) Mortality, and migration in the Cape Colony, 1891-1904. International Journal of African Historical Studies 22(1): 79-111.

Smits, J.P. (2006) Economic growth and structural change in Sub Saharan Africa during the twentieth century: new empirical evidence. Unpublished paper presented at the International Economic History Association Conference, Helsinki. 


\section{IMPROVING HUMAN DEVELOPMENT}

Smits, J.P., Horlings, E. and van Zanden, J.L. (2000) Dutch GNP and its Components, 1800-1913. Groningen: Groningen Growth and Development Centre Research Monograph no. 5.

Srb, V. (1962) Population development and population policy in Czechoslovakia. Population Studies 16(2): 147-159.

Srinivassan, T.N. (1994) Human development: a new paradigm or reinvention of the wheel? American Economic Review, Papers and Proceedings 84(2): 238-243.

Stadler, J.J. (1963) The gross domestic product of South Africa 1911-1959. South African Journal of Economics 31(3): 185-208.

Statistics Canada (2004) Historical Statistics of Canada. Available at http://www. statcan.ca/ (last accessed 25 July 2009).

Steckel R.H. and Floud R. (eds) (1997a) Health and Welfare during Industrialization. Chicago, IL: University of Chicago Press.

Steckel, R.H. and Floud, R. (1997b) Conclusions. In R.H. Steckel and R. Floud (eds), Health and Welfare during Industrialization (pp. 423-449). Chicago, IL: University of Chicago Press.

Streeten, P., Burki, S., Haq, M., Hicks, N. and Stewart, F. (1981) First Things First: Meeting Basic Human Needs in Developing Countries. New York: Oxford University Press.

Summers, R. and Heston, A. (1991) The Penn World Table (mark 5): an expanded set of international comparisons, 1950-1988. Quarterly Journal of Economics 106: $327-368$.

Taira, K. (1971) Education and literacy in Meiji Japan: an interpretation. Explorations in Economic History 8: 371-394.

Tomlinson, B.R. (1993) The Economic History of Modern India, 1860-1970. Cambridge: Cambridge University Press.

van Tonder, J.L. and van Eeden, I.J. (1975) Abridged Life Tables for All the Population Groups in the Republic of South Africa (1921-70). Pretoria: Institute for Sociological, Demographic and Criminological Research, Human Sciences Research Council.

Toutain, J.C. (1997) Le produit intérieur brut de la France, 1789-1990. Economies et Societés. Histoire Economique Quantitative 1(11): 5-136.

Tsai, W.-H. (2008) The growth of Taiwan's aging population and its socio-economic consequences. Taiwanese Gerontological Forum 1(1): 1-10; http://www.ncku.edu.tw/ forum/vol1/article1 (last accessed 13 March 2010).

Tsui, K.-Y. (1996) Improvement indices of well-being. Social Choice and Welfare 13(3): 291-303.

UNESCO (1953) Progress of Literacy in Various Countries. A Preliminary Statistical Study of Available Census Data since 1900. Paris: UNESCO.

UNESCO (1957) World Illiteracy at Mid-Century. A Statistical Study. Paris: UNESCO.

UNESCO (1970) Literacy 1967-1969: Progress Achieved in Literacy throughout the World. Paris: UNESCO.

UNESCO (2002) Estimated Illiteracy Rate and Illiterate Population Aged 15 Years and Older by Country, 1970-2015. Paris: UNESCO.

UNESCO (2010) Total Enrolment, School Life Expectancy, and Expenditure on Education 1970-2005. Paris: UNESCO.

United Nations (1954) Report on International Definition and Measurement of Standards and Levels of Living. New York: United Nations.

United Nations (1993) Demographic Yearbook 1991 Special Issue: Population Ageing and the Situation of Elderly Persons. New York: United Nations.

United Nations (2000) Demographic Yearbook Historical Supplement 1948-1997. New York: United Nations.

United Nations Development Programme (UNDP) (1990) Human Development Report. New York: Oxford University Press. 


\section{ESCOSURA}

United Nations Development Programme (UNDP) (1993) Human Development Report. New York: Oxford University Press.

United Nations Development Programme (UNDP) (2001) Human Development Report. New York: Oxford University Press.

United Nations Development Programme (UNDP) (2009) Human Development Report. New York: Oxford University Press.

Urquhart, M.C. (1993) Gross National Product, Canada 1870-1926: The Derivation of the Estimates. Kingston: McGill-Queen's University Press.

Valaoras, V. (1960) A reconstruction of the demographic history of modern Greece. Miliband Memorial Fund Quarterly 38: 114-139.

Valério, N. (2001) Estatísticas Históricas Portuguesas, 2 vols. Lisboa: Instituto Nacional de Estatística

Vallin, J. (1976) La population de la Thailande. Population 31(1): 153-175.

Vamplew W. (ed.) (1987) Australians. Historical Statistics. Broadway: Fairfax, Syme, and Weldon.

Veiga, R.T. (2005) A transiçao demográfica. In P. Lains and A. Ferreira da Silva (eds), História Económica de Portugal 1700-2000. Vol. III: O Século XX (pp. 37-63). Lisboa: Impresa de Ciências Sociais.

Viñao Frago, A. (1990) The history of literacy in Spain: evolution, traits, and questions. History of Education Quarterly 30(4): 573-599.

Visaria, L. and Visaria, P. (1982) Population (1757-1947). In D. Kumar (with M. Desai) (ed.), Cambridge Economic History of India, 2 vols. (Vol. II), pp. 463-532. Cambridge: Cambridge University Press.

Ward, M. and Devereux, J. (2003) New evidence on catch-up and convergence after 1870. Mimeo, Department of Economics, Loyola College, Baltimore, MD.

Ward, M. and Devereux, J. (2009) The road not taken: pre-revolutionary Cuban living standards in comparative perspective. Mimeo, Department of Economics, Loyola College, Baltimore, MD.

Whitwell, G., de Souza, C. and Nicholas, S. (1997) Height, health, and economic growth in Australia. In R.H. Steckel and R. Floud (eds), Health and Welfare during Industrialization (pp. 379-422). Chicago, IL: University of Chicago Press.

World Bank (2010) World Development Indicators Database, Washington, DC: World Bank; http://data.worldbank.org/data-catalog (last accessed 5 June 2010).

Yousef, T.M. (2002) Egypt's growth performance under economic liberalism: a reassessment with new GDP estimates. Review of Income and Wealth 48(4): 561-579.

Zamagni, V. (1990) Dalla Perifería al Centro. La seconda rinascita economica dell'Italia 1861-1981. Bologna: Il Mulino.

\section{Data Appendix}

\section{Life Expectancy at Birth}

Life expectancy is defined in the 'Technical Notes' to the United Nations (2000), Demographic Yearbook Historical Supplement 1948-1997, as 'the average number of years of life which would remain for males and females reaching the ages specified if they continued to be subjected to the same mortality experienced in the year(s) to which these life expectancies refer'. In the Life Tables, estimates are based on the assumption that 'the theoretical cohort is subject, throughout its existence, to the age-specific mortality rates observed at a particular time. Thus levels of mortality prevailing at the time a life table is constructed are assumed to remain unchanged into the future until all members of the cohort have died'. 
Unless reference is made to a specific country's sources, UNDP Human Development Report (2009) provides the data for most countries over 1980-2005. The United Nations (2000), Demographic Yearbook Historical Supplement, provides the data from 1950 onwards. Pre-1950 data come from Flora (1983), vol. II, for Western Europe, and for Latin America from Astorga et al. (2003) OxLAD database (which Pablo Astorga kindly supplemented with the working sheets prepared by Shane and Barbara Hunt), completed for the 19th century with Arriaga (1968). Riley (2005c) has proved to be extremely useful both for the references it provides as for the data included in it.

Exceptionally, in the absence of life expectancy estimates for early years, its level has been obtained by projecting available data with infant survival rates. This is the procedure was used to distribute the average life expectancy estimate for Argentina, 1869-1894; and to derive life expectancy for Jamaica, 1880-1900; Panama, 1900-1929; Guyana, 1950-1960; and Yugoslavia, 1929-1950.

\section{Africa}

Most pre-1950 estimates come from Riley (2005b) who points out that the earliest health transition started in the 1920s when mean and median values were 26.4 and 25.4 years, respectively. Strong assumptions were needed. Lower bound estimates for 1950 or 1940s levels were used for 1938, whereas prior to 1929 life expectancy at birth was assumed to be 25 years (the minimum goalpost) for Sub Saharan Africa unless specified below:

- Algeria, 1930s, Riley (2005b); 1920s, assumed to be the same as Tunisia's.

- Angola, 1938, Riley (2005b).

- Benin, 1938, Riley (2005b).

- Cameroon, 1929 and 1933, and 1938 (assumed to be equal to the lower bound estimate for 1950), Riley (2005b).

- Angola, Benin, Chad, Eritrea, Ethiopia, Gabon, Gambia, Niger, Sudan, Togo, 1929-1933, assumed to be as Nigeria's.

- Burkina Faso, Burundi, CAR, Congo, Congo Dem. Rep., Côte d'Ivoire, Liberia, Mali, Mauritania, Rwanda, Tanzania, 1929-1933, assumed to be as in Ghana.

- Côte d'Ivoire, 1938, Riley (2005b).

- Egypt, 1929-1938, Fargues (1986); 1925, assumed to be similar to Tunisia's.

- Ethiopia, 1938, Riley (2005b).

- Ghana, 1920, Riley (2005b); 1933, Bourguignon and Morrison (2002).

- Kenya, Riley (2005b) provides an estimate of 23.5 years for the 1930s. Thus, the minimum goalpost of 25 years was assigned to the pre-1938 period.

- Lesotho, Madagascar and Malawi, 1925-1933, assumed to be as in Mauritius.

- Mauritius, 1920s, Riley (2005b); 1930s, assumed to be the same as in 1942-1946, United Nations (1993).

- Morocco, 1925-1938, assumed to be as Tunisia's.

- Mozambique, 1929-1938, assumed to be as in Angolas. 
- Namibia, 1870-1900, assumed it evolves as South Africa; 1900, assumed to be the same as for blacks in Cape Colony from Simkins et al. (1989); 1938, Notkola et al. (2000, p. 161). Northern Namibia figure adjusted with the ratio all Namibia to Northern Namibia c. 1960. It does not change over 1900-1938.

- Nigeria, 1929-1933, average of Ayeni (1976) for 1931, cited in Riley (2005b).

- Senegal, 1938, average of Riley (2005b).

- South Africa, 1880-1925, Simkins et al. (1989); 1929-1938, van Tonder and van Eeden (1975), cited in Riley (2005b).

- Tunisia, 1920s, Riley (2005b); 1930s, assumed to be the same as Algeria's.

- Uganda, 1930s (c. 1935), 23.9 (Riley, 2005b), so I have assigned the minimum goalpost for 1850-1938.

- Zambia, 1929-1938, assumed to be the same as Zimbabwe's.

- Zimbabwe, 1930s, 26.4 (Riley, 2005b). I have assigned the minimum goalpost over 1850-1929.

\section{The Americas}

- Argentina, 1870-1890, Recchini de Lattes and Lattes (1975).

- Canada, United Nations (2000) level for 1938 backwards projected for pre1938 period with Bourbeau et al. (1997) in order to maintain consistency over time.

- Chile, 1890-1900, and Uruguay, 1870-1900, assumed to have evolved along Argentina.

- Uruguay, 1900-1938, Ministerio de Salud Pública (2001),

- Life expectancy in Columbia, 1870-1900, and Cuba, 1860-1900, Panama, 1880-1900, Honduras, 1890-1900, Puerto Rico, 1860-1890 and Venezuela, 1880-1900, has been assumed to evolve along Costa Rica's.

- Paraguay, 1900, Arriaga (1968).

- Peru, 1913-1938, has been assumed to evolve along Bolivia's and Puerto Rico, 1900-1950 along Cuba's.

- Puerto Rico, 1860-1890, assumed it evolves along Costa Rica; 1890, Riley (2005b); 1900-1938, United Nations (1993).

- Trinidad and Tobago, 1860-1900, assumed to have evolved along Jamaica's.

- USA, up to 1890, Haines (1994).

- Uruguay, 1913-1938, Ministerio de Salud Pública (2001).

Asia

Most pre-1950 estimates come from Riley (2005b) who claims that the earliest health transition started in the 1870/1890s when mean and median values were 27.5 and 25.1 years, respectively. Strong assumptions were have been accepted. Lower bound estimates for 1950 or 1940s levels were used for 1938, whereas prior to 1929 life expectancy at birth was assumed to be 25 years (the minimum goalpost) unless specified below:

- Cambodia, 1938, Siampos (1970), cited in Riley (2005b); 1929-1933, assumed it evolved along China as they had similar levels in 1925 and 1938. 
- China, 1938 and 1925, upper and lower bound in 1925-1936, respectively, Riley (2005b); 1929-1933, Caldwell et al. (1986), cited in Lavely and Wong (1998).

- Hong Kong SAR, assumed to have evolved at the same rate of variation as Taiwan's, 1900-1938.

- Cyprus, up to 1933, since in Cyprus and Greece life expectancy levels were identical in 1890 and very close in 1938, I assumed they were the same over the period. Figures for 1890, from Riley (2005b).

- India, 1890-1938, McAlpin (1983); extrapolated to 1880 with Visaria and Visaria (1982).

- Indonesia, 1920s, Riley (2005b).

- Japan, 1870, Riley (2005b); 1880, Janetta and Preston (1991); 1890-1900, Johansson and Mosk (1987).

- Korea, 1913, Riley (2005b) for 1915, 23.5 years. Since I assumed the historical lower bound to be 25 years, this value was assigned to the pre-1913 era; 1920s-1933, adding 0.87 years per annum as suggested by Riley (2005b); 1938, United Nations (1993).

- Lao PDR, 1929-1933, assumed to evolve as Vietnam's.

- Malaysia, 1929-1938, 1950 level backwards projected with the infant survival rate.

- Nepal, 1925-1933, assumed to evolve as India.

- Singapore, 1929-1938, 1950 level backwards projected with the infant survival rate; 1870-1925, assumed to evolve at the same pace as Malaysia's.

- Sri Lanka, 1890-1925, 1938, Langford and Storey (1993); 1929, Sarkar (1951), 1929-1933.

- Taiwan, 1890-1938, 1955, Cha and Wu (2002); 1950, Glass and Grebenik (1967); 1980-2005, english.moe.gov.tw/public/Attachment/ 9101916565871.pdf; 2000-2005, Tsai (2008).

- Thailand, 1938, Vallin (1976).

- Turkey, pre-1913,1920s and 1930s, assumed it evolved at the same rate of change as Greece's; 1913, Pamuk (2007); 1938, Shorter and Macura (1982).

\section{Oceania}

Australia, 1870-1900, Whitwell et al. (1997).

- New Zealand (adjusted for Maori population), 1870, Riley (2005b); 1880-1890, Glass and Grebenik (1967).

\section{Europe}

- Austria, 1870, Helczmanovski (1979); 1880-1890, interpolated from Helczmanovski (1979), Glass and Grebenik (1967, p. 82) and the United Nations (1993).

- Belgium, Deprez (1979), 1870, and Flora (1983), 1880-1900. Interpolation with United Nations (1993) for 1928/1932.

- Bulgaria, 1870-1890, assumed to move along Greece's. 
- Cyprus, since in Cyprus and Greece the levels in 1890 were identical and in 1950 very close, I assumed they were the same over the period up to 1938.

- Czechoslovakia, 1870-1913, Sbr (1962); for 1890, Riley (2005b).

- Finland, up to 1990, Kannisto et al. (1999).

- France, 1870-1900, Flora (1983).

- Germany, 1870-1890, Flora (1983).

- Greece, pre-1913, Valaoras (1960).

- Hungary, 1870-1900, assumed to evolve along Austria's.

- Ireland, 1850-1900, assumed to evolve along the UK's.

- Italy, 1881 and 1901, Zamagni (1990); 1870-1938, Conte et al. (2007).

- Poland, 1870-1913, assuming it evolved as Czechoslovakia's.

- Portugal, 1850-1933, Leite (2005); 1920-1930, Veiga (2005); 1925-1929, Valèrio (2001).

- Romania, assumed to evolve along Greece, 1870-1890, and along Bulgaria's, 1890-1929.

- Russia, Pressat (1985), European Russia, 1870-1913; European Soviet Union, 1925-1933; Soviet Union, 1938.

- Baltic Republics, Ukraine, 1900, 1935, Riley (2005b), Mazur (1969).

- Spain, Dopico and Reher (1998), 1870-1938; 1950-2000, Nicolau (2005) and Goerlich and Pinilla (2005).

- Sweden, 1870-1965, Sandberg and Steckel (1997), taken from Keyfitz and Fleiger (1968).

- UK, 1850-1900, Floud and Harris (1997).

- Yugoslavia, assumed to evolve along Greece's, 1870-1890, and along Bulgaria's, 1890-1929.

\section{Literacy}

The rate of adult literacy is defined as the percentage of population aged 15 years or over who is able to read and write. Although from a conceptual point of view there are no objections to the UNESCO definition of literate person, namely, 'who can, with understanding, both read and write a short simple statement on his everyday life' (quoted in Nilsson, 1999, p. 278), assessing a person's literacy is quite a different issue. Empirically, literacy is a far from uniform a concept. On the one hand, reading and writing do not necessarily go together in developing countries and it has been shown that, prior to the diffusion of the schooling system, the lag between acquiring the ability to read and to write can be as wide as a century or more (Markussen, 1990; Nilsson, 1999) and, therefore, the estimated literacy rate would vary wildly depending on whether a wide (read ability only) or a narrow (reading and writing skills) definition of literacy is used, and how it is actually measured (with marriage signatures being particularly misleading in pre-industrial societies). Moreover, becoming literate is far more difficult and time intensive in countries which languages employ Chinese characters (Taira, 1971; Honda, 1997). In practice, although classifying a person as truly literate should imply that she is able to read and write, it not always possible make such a precise distinction for 
the past (Nilsson, 1999, p. 279). This has led to historians to focus on estimating the share of illiterate population (Flora, 1973). Unfortunately, historical data are far from homogeneous and, therefore, the results will suffer from biases which, nonetheless, will not condition long run trends.

The UNDP Human Development Report (2009) provides most of the data for 1980-2005. Unless reference is made to a specific country's sources, data from 1950 onwards come from the UNESCO $(1953,1957,1970,2002)$ and World Bank (2010), completed with data from Banks (2010), Hayami and Ruttan (1985) and Easterly (1999), and additional data for 1850-1965 come from Flora (1973). As regards different world regions, Flora (1983) provides data for Western Europe, whereas data for Latin America in the 20th century come from Astorga and Fitzgerald (1998) and Astorga et al. (2003) OxLAD database (which Pablo Astorga kindly supplemented with their working sheets prepared by Shane and Barbara Hunt), completed with Newland (1991) for the 19th century.

Exceptionally, in the absence of estimates, literacy rates have been backwards projected with the rate of primary enrolment or the years of primary education (Morrisson and Murtin, 2009). Also, for the post-1960, in its absence, it has been derived by assuming the illiteracy rate to be identical to the share of population without any schooling from data in Barro and Lee (2002) and Cohen and Soto (2007).

\section{Africa}

There is uncertainty about literacy rates even in recent times as evidenced by the wide discrepancies between UNESCO and UNDP figures for 16 countries out of 53 over the years 1980-1995. In order to keep consistency with UNDP's HDR I have opted for the latter with a few exceptions (Algeria 1990-1995, Botswana 1980-1985).

- Guinea, Madagascar, Mali, Mauritius, Niger, Senegal and Togo, 1970-1980, Ouane and Amon-Tanoh (1990).

- Literacy rates have been projected backwards with the rate of primary enrolment for Algeria, 1870-1880, 1930s; Burundi, 1929; Cape Verde, Equatorial Guinea, Guinea, Zambia, 1929-1938; Ghana 1880-1938; Kenya, Sudan and Tanzania,1920-1938; Lesotho and Liberia, 1890-1938; Mauritius, 1870-1933; Namibia, Nigeria, Togo and Zimbabwe, 1913-1938; Seychelles and Sierra Leone, 1900-1938; South Africa, 1925-1933; Uganda, 1920-1938.

- Literacy rates have been backwards projected with years of primary education for the population above 15 years (Morrisson and Murtin (2009) for Angola, Cameroon, Côte d'Ivoire, Madagascar, Malawi, Mali, Mozambique and Senegal 1870-1938; Eritrea and Ethiopia, 1870-1933; Kenya and Uganda, 1870-1913; Sierra Leone and Tunisia, 1870-1890).

- Namibia, 1870-1913, assumed to evolve along South Africa; Botswana and Swaziland, 1870-1938, assumed to be the same as Namibia's. Libya, 1870-1900, assumed to be as Morocco's. 
The Americas

- Chile, 1870, Braun et al. (2000).

- Cuba, 1870-1890, Newland (1991).

- Nicaragua, 1900, Núñez (2005).

- USA, 1870-1890, 1960-1970, Costa and Steckel (1997).

- Literacy rates have been backwards projected with the rate of primary enrolment for Bahamas, 1890-1900; Barbados, 1870-1938; Belize, 1870-1900; Bolivia, 1870-1890; Guyana, 1870-1900; Puerto Rico, 1870-1890.

- Literacy rates have been backwards projected with years of primary education for the population above 15 years (Morrisson and Murtin (2009) for Dominican Republic, 1870-1900; El Salvador, 1870-1890; Uruguay, 1870-1890; Venezuela, 1870-1880).

- Trinidad and Tobago, St. Kitts, St. Lucia, St. Vincent and the Grenadines, and Surinam, assumed to evolve along Jamaica over 1870-1890.

Asia

- China, 1870, 1913, Morrisson and Murtin (2007).

- India, 1890, 1938, Tomlinson (1993).

- Japan, 1870, Steckel and Floud (1997b); 1880-1890 (assuming the rate of primary enrolment was a good approximation), Hanley (1990); 1900-1938, Honda (1997).

- Korea, 1929-1933, Kimura (1990).

- Australia, 1870, Vamplew (1987) 1890-1900, Steckel and Floud (1997b).

- Literacy rates have been projected backwards with the rate of primary enrolment for Cambodia and Laos, 1913-1938; China, 1929-1933; Hong Kong, 1870-1925; India, 1870-1880, 1920s; Indonesia, Taiwan and Vietnam, 1900-1938; Iran, Jordan, Malaysia and Myammar, 1920s; Israel, Lebanon, Sri Lanka and Syria, 1920-1938; Korea, 1913-1925; Fiji, 1900-1913, 1925-1938.

- Literacy rates have been backwards projected with years of primary education for the population above 15 years (Morrisson and Murtin (2009) for Iraq, 1870-1938; Malaysia, 1870-1900; Myammar, 1870-1880; Philippines, 1870-1913; Syria, 1870-1900; Thailand, 1880-1920, 1929).

\section{Europe}

- Austria, 1880-1913, Flora (1983).

- Belgium, 1938, 1955, Banks (2010).

- Bulgaria, 1955, 1965, Banks (2010).

- Czechoslovakia, 1880-1900, Flora (1983); 1938, 1955, 1965, Banks (2010).

- Finland, 1870, Crafts (1997); 1880-1890, Myllantaus (1990); 1900, Flora (1983); 1925-1960, Banks (2010).

- Germany, 1950, 1955, Banks (2010).

- Greece, 1925-1955, Banks (2010).

- Ireland, 1870-1900, Flora (1983); 1913, Crafts (1997). 
- Italy, 1870-1880, Flora (1983); 1890, 1960, Conte et al. (2007); 1925, 1938, 1955, Banks (2010).

- Poland, 1870-1890, assumed to evolve along Hungary's; 1900, Flora (1983); 1920-1965, Banks (2010).

- Portugal, 1880, Reis (1993); 1880-1890, 1913-1938, 1955-1965, Nunes (1993).

- Romania, 1920-1965, Banks (2010).

- Russia, 1870-1960, Mironov (1991, 1993).

- Spain, 1870-1880, Núñez (2005); 1890-1930, Reher (personal communication); Viñao Frago (1990).

- Sweden, 1870-1965, Banks (2010).

- Yugoslavia//Serbia, 1920-1990, Banks (2010).

- UK, 1870-1965, Banks (2010).

- Literacy rates have been backwards projected with the rate of primary enrolment for Albania, 1920-1938; Cyprus, 1880-1900; Estonia, 1938-1965; Luxembourg, 1929-1938; Malta, 1890-1900.

- Literacy rates have been backwards projected with years of primary education (Morrisson and Murtin (2009) for Bulgaria, 1870-1880).

\section{Enrolment}

The enrolment ratio is computed by referring the number of students, at a particular education level, to the relevant school age population. Historical evidence allows one to estimate the rate of unadjusted enrolment defined as the percentage of population aged 5-24 enrolled in primary, secondary and tertiary education. Enrolment rates basically capture the expansion of formal education and do not inform about the length of the academic year, students' attendance, the content and quality of education or students' performance and completion (see Benavot and Riddle (1988) for a detailed discussion of its shortcomings and biases). Figures on enrolment, apparently straight forward, present difficulties of interpretation. The usual measurement procedure is to divide the number of students by the relevant school-age population cohort, for example, primary enrolment rate as the share of children receiving primary education over population aged 5 to 14 years, keeping this yardstick fixed over time (namely, the unadjusted enrolment rate). Usually, however, such age span is longer that primary schooling, leading to an underestimate and, even worse, comparability is fraught with difficulties as the length of primary or secondary schooling changes across countries and over time and, therefore, biases of unknown sign are introduced (Benavot and Riddle, 1988, p. 195; Nilsson, 1999 , p. 282). Alas, up to the mid-20th century, the only kind of enrolment rate that can be easily computed for a large number of countries and over a long time span is the unadjusted one. Later, international organizations (UNESCO, OECD, World Bank) have provided gross enrolment rates, in which the denominator is adjusted to the age bracket for which each type of schooling (primary, secondary etc) is provided. Here the difficulty is that enrolment rates above $100 \%$ can appear as under- and/or over-age students are included in the numerator. Eliminating them 
is thus required, and the result is the unusually available net enrolment rate. In the present case, since the numerator includes primary, secondary and tertiary enrolment numbers and the denominator, population aged 5-24, the differences between gross and net rates tend to be negligible. However, the unadjusted rate will usually underestimate the actual enrolment rate as in the past hardly any country's education extended to those age 24 years. Thus, I have corrected the bias in my historical estimates (here, pre-1980) with the ratio for 1980 between gross all enrolment rates and the unadjusted rates I computed from historical sources.

The UNDP Human Development Report (2009) provides most of the data from 1980 onwards. Unless reference is made to a specific country's sources, enrolment estimates come from Banks (2010) and Mitchell (2003a, b, c) completed with UNESCO (2010) for the period 1970-2005; additional data for Western Europe come from Flora (1983), whereas for Latin America most estimates come from Astorga and Fitzgerald (1998) and Astorga et al. (2003) OxLAD database (which Pablo Astorga kindly supplemented with their working sheets prepared by Shane and Barbara Hunt), completed with Newland (1991) for the 19th century.

As regards the relevant population, I have computed the share of population aged 5-24 (and 5-14) over total population at census years from Mitchell (2003a, b, c) and interpolated them log linearly to derive yearly series that have been, then, multiplied by total population figures, provided by Mitchell (2003a, b, c), and supplemented with those by Banks (2010) and Maddison (2009). The population share of those aged 5-24 years for missing African and Asian countries have been replaced with the one from a neighbour country with a similar demographic transition.

For the pre-World War II era, Benavot and Riddle (1988) and Lindert (2004) provide useful estimates of primary and primary and secondary education enrolment rates, respectively, that in the absence of direct sources, have been used.

Occasionally, the all (i.e. primary, secondary and tertiary) enrolment rate for 19th and early 20th century Asian and African countries has been obtained by adjusting the primary or primary and secondary enrolment ratio with the ratio resulting of dividing the share of population aged 5-14 years by the share of population aged 5-24. This crude procedure implies the assumption that secondary and tertiary enrolment numbers represent a tiny proportion of the relevant population cohort.

\section{Africa}

- Algeria, 1870-1960, Fargues (1986).

- Tunisia, 1925-1938, 1960, Fargues (1986).

Population aged 5-24 (and 5-14) share in total population for missing countries. Nigeria's has also been accepted for Benin, Cameroon, Equatorial Guinea and Togo. South Africa's has been adopted for Botswana, Lesotho, Namibia and Swaziland. Mali's for Burkina Faso, CAR, Chad, Congo, Gambia, Guinea, Guinea-Bissau, Mauritania, Niger and Senegal. Uganda's for Burundi, Congo D.R. and Rwanda. Ghana's for Cape Verde, Côte d'Ivoire, Gabon, Liberia and Sierra Leone. Kenya's 
for Somalia. Mozambique's for Comoros and Madagascar. Egypt's for Djibuti, Ethiopia and Sudan. Algeria's for Lybia. Tanzania's for Malawi.

All enrolment derived with primary enrolment in Benavot and Riddle (1988), adjusted to all enrolment with the ratio of those aged 5-14 years to those aged 5-24 years, for Benin, Sudan, 1925-1933; Cameroon, 1890-1933; Congo, Madagascar, Tanzania and Uganda 1920-1938; Côte d'Ivoire, 1938; Egypt, 1890-1913; Gabon, 1925-1938; Gambia, 1900-1929; Kenya, 1920, 1938; Lesotho, 1890-1938; Mauritius, 1880, 1929, 1938; Mozambique and Zambia, 1938; Namibia, Togo, 1913-1938; Reunion and Seychelles, 1900-1938; Senegal, 1929-1933; Botswana, 1955-1960; Swaziland, 1955-1965; Namibia, 1870-1913, 1950-1980, assumed to evolve along South Africa; Zambia, assumed to evolve along Zimbabwe, 1870-1925. Botswana and Swaziland, 1870-1938, assumed to be the same as Namibia's. Libya, 1920-1938, assumed to be as Morocco's. Bahrain, 1950-1970, and Brunei-Darussalam, Oman, Qatar and UAE, 1950-1980, assumed to evolve along Kuwait's.

All enrolment rates have been backwards projected with years of primary education for the population above 15 years (Morrisson and Murtin (2009) for Angola, 1870-1950; Egypt, 1870-1880; Kenya, 1870-1913; Madagascar and Zimbabwe, 1870-1900; Malawi, 1870-1890; Mali, 1890-1938; Mozambique, 1870-1920; Tunisia, 1870-1890; Uganda, 1870-1913).

\section{The Americas}

- Puerto Rico, 1870-1880, Newland (1991).

- Venezuela, 1870-1890, Newland (1991).

- All enrolment derived with primary enrolment in Benavot and Riddle (1988) adjusted to all enrolment with the ratio of those aged 5-14 years to those aged 5-24 years, for Bahamas, Barbados, Belize, St Kitts, St Lucia, St Vincent and Surinam, 1890-1938; Dominican Rep., 1870-1913; Ecuador, 1870-1880; Guyana, 1870-1900.

- All enrolment rates have been backwards projected with years of primary education for the population above 15 years (Morrisson and Murtin (2009) for Cuba, 1870-1890; Honduras, 1870-1880; Panama, 1870-1890; Paraguay, 1870-1880).

- Trinidad and Tobago, St. Kitts, St. Lucia, St. Vincent and the Grenadines, and Surinam, assumed to evolve along Jamaica's over 1870-1890.

Asia

- China, 1890-1913, assumes it evolved at the same pace as Hong Kong.

- Population aged 5-24 (and 5-14) share in total population for missing countries. Syria's for Lebanon. China's for Nepal.

- All enrolment derived with primary enrolment in Benavot and Riddle (1988) adjusted to all enrolment with the ratio of those aged 5-14 years to those aged 5-24 years, for Cambodia, 1920-1938; Iraq, 1913-1925; Israel and 
Laos, 1920-1938; Lebanon, 1920; Philippines, Taiwan and Fiji, 1900; Syria, 1900-1920.

- All enrolment rates have been backwards projected with years of primary education for the population above 15 years (Morrisson and Murtin (2009) for India and Myanmar, 1870; Iran and Iraq, 1870-1900; Philippines and Syria, 1870-1890; Thailand, 1800-1900; Turkey, 1870-1880).

- Hong Kong assumed to have evolved as China, 1955-1980, and Kuwait as Iraq, 1950-1960.

\section{Europe}

- Italy, 1870, 1913, 1929, Conte et al. (2007).

- Portugal, 1880-1913, Reis (1993), primary enrolment.

- Spain, 1870-1985, Núñez (2005).

- Population aged 5-24 (and 5-14) share in total population for Cyprus, Turkey's and Greece's, weighted by the shares of Turkish and Greek in total population.

- All enrolment derived with primary enrolment in Benavot and Riddle (1988) adjusted to all enrolment with the ratio of those aged 5-14 years to those aged 5-24 years, for Czechoslovakia, 1913; Denmark, 1870; Estonia, Latvia, Lithuania, 1920-1938; Luxembourg, 1929-1950; Malta, 1890-1950; Romania, 1870.

- All enrolment derived with primary and secondary enrolment in Lindert (2004) adjusted to all enrolment with the ratio of those aged 5-14 years to those aged 5-24 years (Mitchell, 2003c), for Ireland, 1870-1900; Italy, 1870; Portugal, 1920; Switzerland, 1870; UK, 1870-1900.

- All enrolment rates have been backwards projected with years of primary education for the population above 15 years (Morrisson and Murtin (2009) for Bulgaria, 1870-1880).

\section{Per Capita GDP}

Most data come from Maddison (2006, 2009) up to 1990, and Conference Board (2010), since 1995 (although sometimes for the post-1950 period as it is in the case of China, since Conference Board has adjusted the estimates to the recent findings in the 2005 PPP round), and are expressed in 1990 Geary-Khamis dollars. Otherwise, for specific countries shown below, Maddison's per capita GDP levels (usually for 1950) are projected backwards with volume indices of real per capita GDP.

\section{Africa}

Estimates for Sub Saharan Africa, West, East and Central-South regions, 1913-1938, come from Smits (2006). The West includes Benin, Burkina Faso, Cape Verde, Côte d'Ivoire, Gambia, Ghana, Guinea, Guinea-Bissau, Liberia, 
Mali, Mauritania, Niger, Nigeria, Senegal, Sierra Leone and Togo. The East, Burundi, Comoro Islands, Djibouti, Eritrea and Ethiopia, Kenya, Madagascar, Malawi, Mauritius, Mozambique, Reunion, Rwanda, Seychelles, Somalia,Tanzania, Uganda, Zambia and Zimbabwe. Central-South, Angola, Cameroon, Central African Republic, Chad, Congo, Congo D.R., Equatorial Guinea, Gabon, São Tomé and Principe, Sudan, Botswana, Lesotho, Namibia, South Africa and Swaziland.

Levels for each country within each Sub-Saharan region over 1913-1938 were derived by projecting backward per capita GDP in 1950 (from Maddison, 2009) with Smits (2006) regional aggregate volume series. For the period 1870-1913, I assumed Benin, Côte d'Ivoire, Gabon, Liberia and Senegal evolved along Ghana's. For the rest of the countries I assigned the lower bound for per capita income (1990 \$300) as their levels were around or below such level by 1913. This way I was able to derive income levels to combine with education and life expectancy indices into a human development index for each country. Once national HDI were obtained, I aggregated them again into Smits' defined three regions, West, East and Central-South, as the individual country values would obviously be highly arbitrary and conjectural.

- For Nigeria, 1870-1913, Bourguignon and Morrisson (2002).

- For Algeria and Egypt, 1870-1950, and Ghana, 1870-1913, estimates come from Maddison (2006, pp. 577-578). I interpolated levels for 1890, 1900, 1925 and 1938 for Algeria. I interpolated levels for Morocco and Tunisia in the years 1880, 1890 and 1900, and then, 1925, 1929, 1933 and 1938 by assuming that these two countries grew at the same pace as Algeria.

- For Egypt, 1870-1950, Maddison (2006, p. 577). Pamuk (2006) and Yousef (2002) also provide estimates. The former figures match closely Maddison's estimates. The latter suggest too low levels for 1870-1913.

- For South Africa, 1913-1950, nominal GDP, Stadler (1963); deflator, Alvaredo and Atkinson (2010). Population comes from Feinstein (2005, pp. 257-258). 1870-1913, estimates for 1913 projected backwards with Bourguignon and Morrisson (2002) levels.

\section{The Americas}

Data for 20th century Latin America comes from CEPAL (2009), from 1950 onwards, and from Astorga and Fitzgerald (1998) and Astorga et al. (2003). Otherwise the sources are:

- Argentina, Della Paolera et al. (2003), 1884-1950, assuming the rate of growth over 1870-1884 was identical to that for 1884-1890. The alternative option of projecting backwards the level for 1884 to 1875 with Cortés Conde (1997) casts too low a figure. I assumed the level for 1870 was identical to that of 1875.

- Brazil, Goldsmith, (1986), up to 1950.

- Chile, Díaz, Lüders and Wagner (2007), up to 1950. 
- Colombia, Kalmanovitz and López Rivera (2009) and data kindly provided by Salomón Kalmanovitz in private communication, up to 1905; GRECO (2002), 1905-1950.

- Cuba, Santamaría (2005), up to 1902; Ward and Devereux (2009), 1902-1958; Maddison (2009), volume series from 1958 onwards. An important caveat is that Maddison (2006) level for 1990 has not been accepted. The reason is that given the lack of PPPs for Cuba in 1990 Maddison (2006, p. 192) assumed its per capita GDP was 15\% below the Latin American average. Since this is an arbitrary assumption, I started from Brundenius and Zimbalist's (1989) estimate of Cuba's GDP per head relative to six major Latin American countries (Argentina, Brazil, Chile, Colombia, Mexico and Venezuela, LA6) in 1980 (provided in Astorga and Fitzgerald, 1998) and applied this ratio to the average per capita income of LA6 in 1980 Geary-Khamis dollars to derive Cuba's level in 1980. Then, following Maddison (1995, p. 166), I derived the level for 1990 with the growth rate of real per capita GDP at national prices over 1980-1990 and reflated the result with the US implicit GDP deflator to arrive to an estimate of per capita GDP in 1990 at 1990 Geary-Khamis dollars. Interestingly, the position of Cuba relative to the USA in 1929 and 1955 is very close to the one derived with a different approach by Ward and Devereux (2009).

- Ecuador, 1870-1890, I assumed it evolved as Peru over 1890-1900 yielding $\$ 470$ for 1890 and I arbitrarily assumed a per capita GDP of $\$ 400$ for $1870-1880$.

- Mexico, Coatsworth (1989, p. 41) for the 19th century. INEGI (1995), 1896-1950.

- Peru, Monasterio (private communication), 1896-1950. I assumed the level for 1890 was the same as for 1896. I also arbitrarily assumed GDP per head for $1870-1880$ was $\$ 400$.

- Uruguay, Bértola (1998), 1870-1938.

- Venezuela, Baptista (1997), up to 1950.

- Central America (Costa Rica, El Salvador, Guatemala, Honduras and Nicaragua): I derived the level for 1913 by assuming the growth over 1913-1920 was identical to that of 1920-1925, the latter derived from OxLAD database (Astorga et al., 2003).

- Caribbean, Bahamas, Barbados, Belize, Guyana, St. Kitts and Nevis, St. Lucia, St. Vincent and the Grenadines and Suriname, Maddison (2006, 2009), Conference Board (2010), and Bulmer-Thomas (personal communication), 1950 onwards.

- Trinidad and Tobago, Maddison (2009), 1950-1970.

- Jamaica, Eisner (1961), 1850-1930; Maddison (2009), 1938 onwards.

- Puerto Rico, Maddison (2009), since 1950.

- Canada, Urquhart (1993), 1870-1926; Statistics Canada (2004), 1926-1976.

- USA, Kendrik (1961), 1869-1953; Bureau of Economic Analysis, since 1953. 
- Estimates for the Middle East, 1870-1913, Pamuk (2006). The countries included are Iran, Iraq, Jordan, Lebanon, Palestine (Israel), Saudi Arabia, Syria, Yemen and the Gulf (Bahrain, Kuwait, Oman, Qatar, UAE) countries.

- Bhutan, Brunei and Maldives, Maddison (2006).

- Korea, 1913-1938, Cha and Kim (2006). 1890, Bourguignon and Morrisson (2002).

- Myammar, 1880-1890, assumed to evolve along India.

- Philippines, 1890, Bourguignon and Morrisson (2002).

- Turkey, 1880, Altug et al. (2008); 1890, Bourguignon and Morrisson (2002).

- Taiwan, 1880-1890, assumed to evolve as China's; 1900, Cha and Wu (2002).

\section{Oceania}

New Zealand, 1870-1938, Greasley and Oxley (2000a, b).

\section{Europe}

- Austria, 1870-1913, Maddison (2009) level for 1913 projected backwards with Schulze (2000) estimates for Imperial Austria under the assumption that real output per head in Modern Austria moved along Imperial Austria's.

- Belgium, up to 1913, Horlings (1997); 1925-38, average of GDP estimates of income and expenditure approaches, Buyst (1997) and Horlings (1997), output.

- Czechoslovakia, Poland, Yugoslavia and Romania, 1880, computed with Good (1994) ratio of 1880 GDP per head to the average GDP per head of 1870 and 1890 applied to Maddison's average levels for 1870 and 1890.

- Cyprus, 1921-1950, Apostolides (private communication). I assumed the level for 1913 was identical to that for 1921.

- Denmark, Hansen (1974), 1850-1938.

- France, Toutain (1997), Yemen.

- Finland, up to 1990, Hjerppe (1996).

- Germany, nominal GDP, 1950-2000, International Monetary Fund (2010); 1901-1913, 1925-1949, Spoerer and Ritschl (1997); 1901 level backwards projected with Hoffmann et al. (1965) to 1870. Real GDP derived by deflating nominal GDP. The deflator comes from International Monetary Fund, 1960-2000; Spoerer and Ritschl (1997), 1901-1960; 1870-1901, Hoffmann et al. (1965).

- Greece, up to 1938, Kostelenos et al. (2007), moving base series.

- Hungary, 1870-1913, Maddison (2009) level for 1913 projected backwards to 1870 with Schulze (2000) estimates for Imperial Hungary, under the assumption that movements in real output per head in Modern Hungary reflected those in Imperial Hungary; Modern (Republic of), as defined by the Treaty of Trianon (1919) 1913-1938, Eckstein (1955, p. 175).

- Italy, 1850-1913, Fenoaltea (2005). 


\section{ESCOSURA}

- Netherlands, up to 1913, Smits et al. (2000), average of income, output and expenditure estimates; 1921-1938, Bakker et al. (1990).

- Norway, Grytten (2004).

- Portugal, 1850-1910, Lains (2006); 1910-1950, Batista et al. (1997).

- Russia, Imperial, 1870-1885, Goldsmith (1961), agricultural and industrial output weighted with Gregory (1982) weights for 1883-1887; 1885-1913, Gregory (1982), Table 3.1; 1913-1928, Markevich and Harrison (2009), Table C-1. Since 1990, Russian Federation.

- Spain, Prados de la Escosura (2003, updated).

- Sweden, Krantz and Schön (2007).

- United Kingdom, 1850-1985, Mitchell (1988).

\section{Population}

All figures are adjusted to refer mid-year and to take into account the territorial changes and are derived from Maddison (2009) and Mitchell (2003a, b, c), completed with Astorga et al. (2003) OxLAD database and CEPAL (2009), for Latin America and the Caribbean, 1900-1938 and 1950-2008, respectively; Banks (2010), for Liberia, Sierra Leone, Ethiopia and Malawi; Fargues (1986), for Algeria and Tunisia; and Nicolau (2005) for Spain. Turkey, 1870-1913, Pamuk (2006, 2007), Cyprus, 1925-1938, Apostolides (private communication). 